
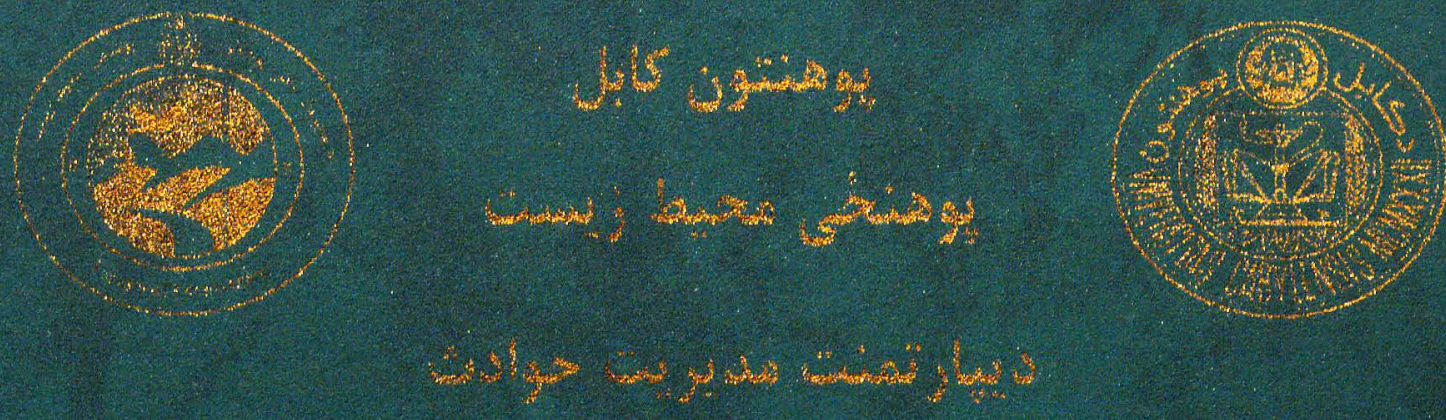

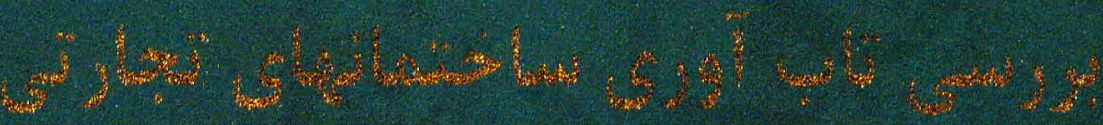

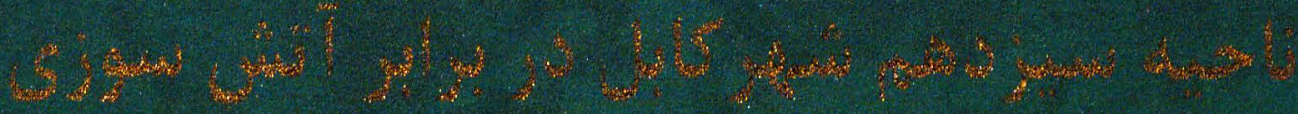




$$
\begin{aligned}
& \text { يوهنتون كابل } \\
& \text { يوهنحَى محيط زيست } \\
& \text { دييار تمنت مديريت حوادث }
\end{aligned}
$$

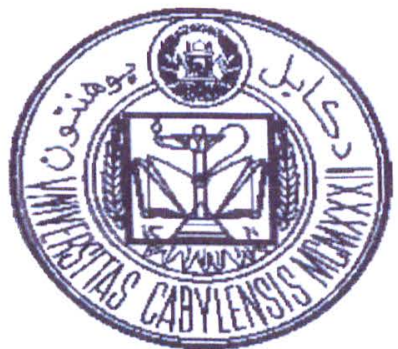

$$
\text { بردسى تاب آورى ساختمانهاى تجارثى }
$$

ناحيه سيز دهم شهر كابل در برابر آتش سوزى

$$
\text { تهييه و تر تيب : محمد على "برنا《) }
$$

استاد راهنما :نامزد يوهنيار شريف الله "ييروز" 


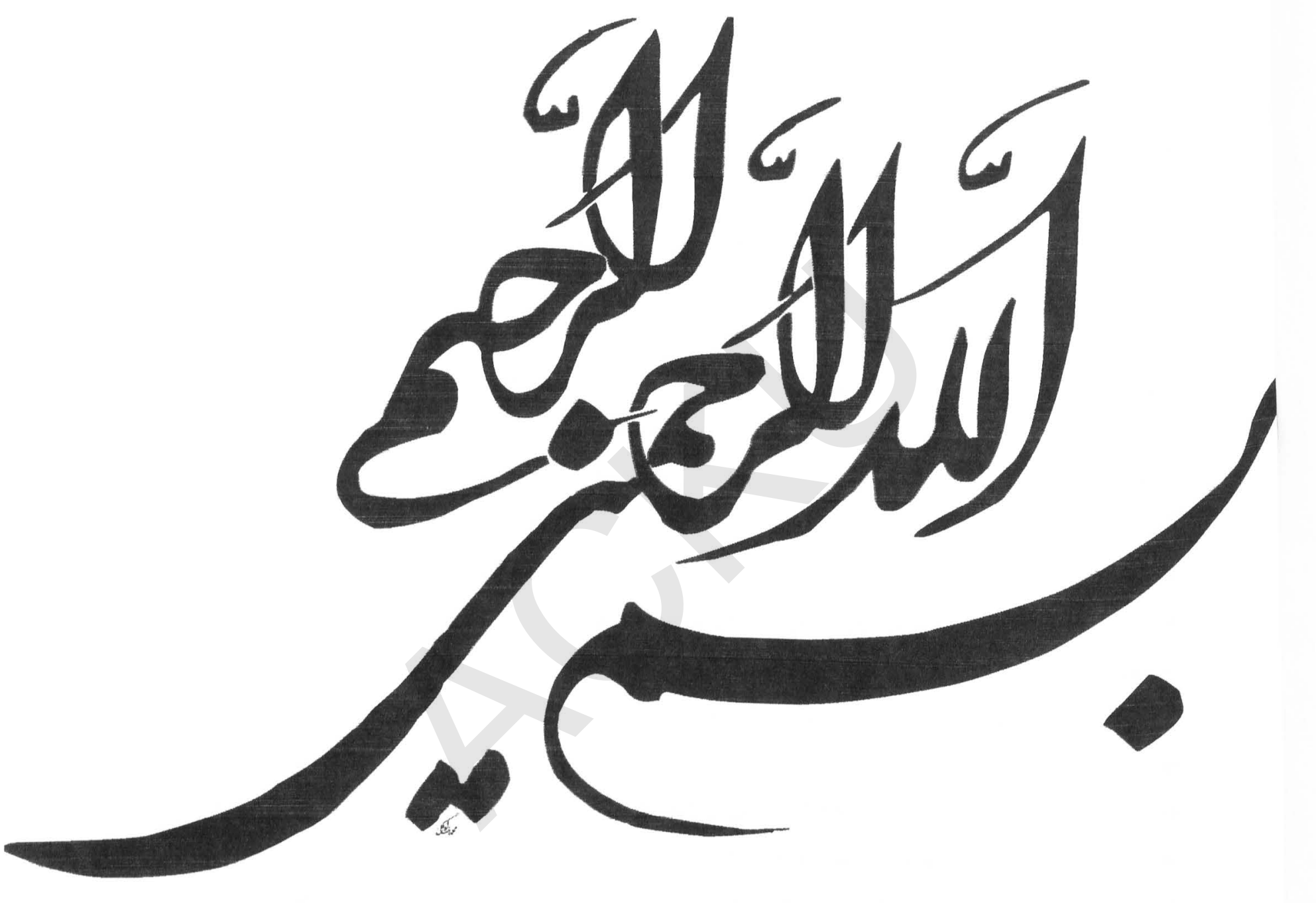




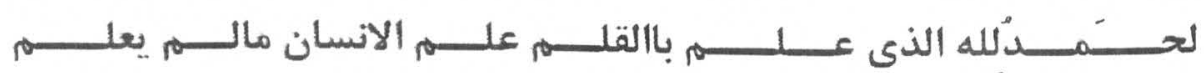

حمد وثناى بى بايان خدايى راست كه انسان رالز عدم به صحند نى وجود آورد وبراى انسان حس كنجكاوى

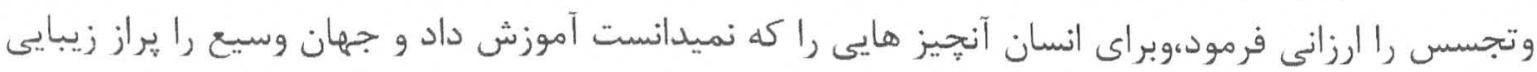
ها وزيشتيها بحيث محيط زيست برايش قرار داد.ودرود فروان بر روان باكى بهترين بنده اش حضرت محمد مصطفى(ص) باد.

انسان ها از آغاز خلقت تا كنون مشغول تحصيل،تفكر وتعقل بوده اند،تابتوانن از اين طريقه در بخش هاى مختلف زندگى تحقيق، كاوش و جستجو كنند تا براى آبادانى و عمران زمينكار وتلاش موضوعات حوادث

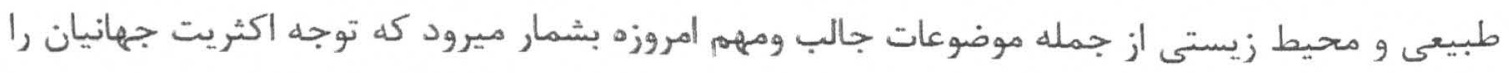
بتود جلب نموده است. و از طرف ديخًر رشد نفوسى وعدم رعايت فرهنت شهر نشينى و ديتًر عوامل مخرب محيط زيستى وحوادث طبيعى باعث ترديده تا محيط زيست و حوادث طبيعى را بطور درست و جدى ندى مديرى كنيم. و حادثه آش سوزى يكى از قديمى ترين آفت و بلاى است كه درين سالهاى اخير در شهر هاى بزرى جهان و بخصوص در شهر كابل افزايش يافته الست. كه در اثر آن مردم سرمايه هاى هنَّفت

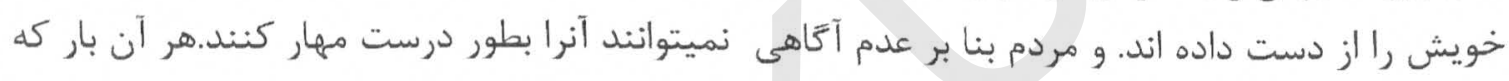

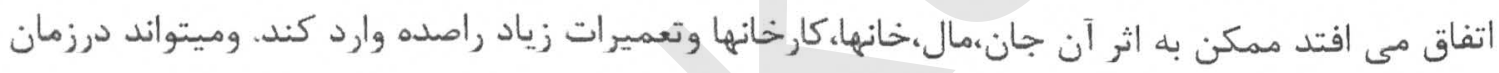

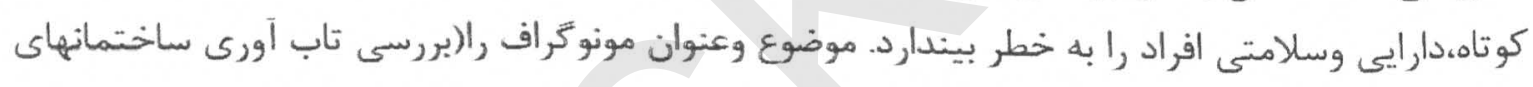
تجارتى ناحيه 13شهر كابل در برابر آتش سوزى) ميباشد.و من به اثر علاقه و شوق ام و با حمايت ورهنماى

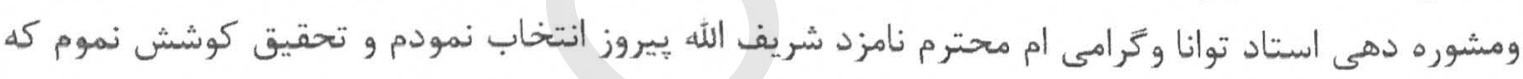

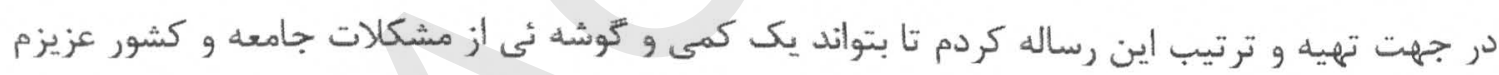
افغانستان را در جهت مديريت آتش سوزى حل نموده و بتوانمر به جامعه ما يان طرز مديريت آتش سوزى و

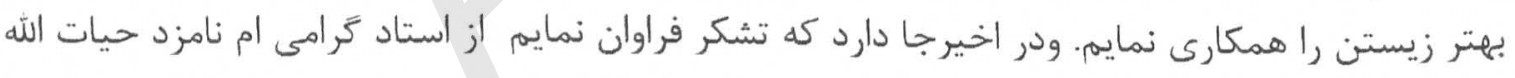

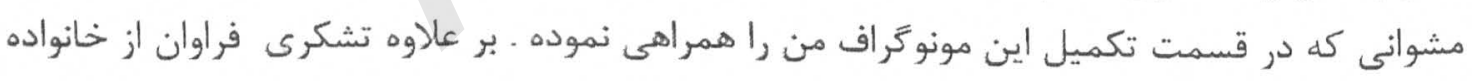

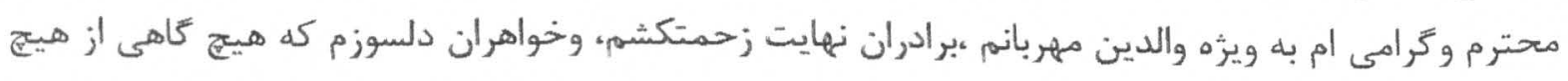

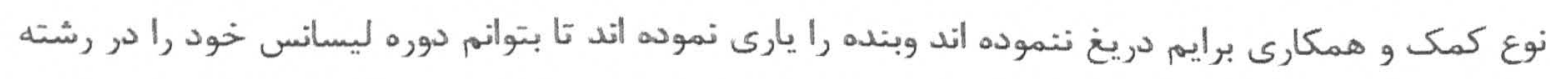
مديريت حوادث به وجه احسن به يايان برسانم. و جادارد كد تشكرى فراوان از حضور تكى تك اساتيد محترمم نمايمه. كه هر يك شان يك التً بوده اند برايمم و هميشه براي تربيت اولاد وطن رنج و زحمت فراوان كشيده اند.

$$
\text { با احترام }
$$

$$
\text { محمد على "برناه" }
$$


در اين تحقيق تاثيرات آتشسوزى بالاى مراكز تجارتى مورد بررسى قرار خواهد كرفت و عواملى كه باعث

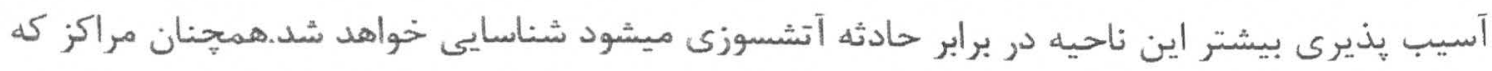

بيشتر در معرض حادثه آتش سوزى واقع ميشوند شناسايى ميشود.اين تحقيق هُندين موضوع مرتبط باتأثيرات آتشسوزى رامورد مطالعه قرار ميدهم. قبل از وارد شدن به موضوع اصلى مباحث عمومى كه شامل طرح مسأله،اهميت تحقيق،اهداف تحقيق و سوالات تحقيق برداخته وبه تعقيب آن نتيجه عمومى را مورد

$$
\text { بحث قرار ميدهم. }
$$

در فصل اول اين تحقيق موضوعات مرتبط به بيشينه تحقيق؛ روش تحقيق،سوالات تحقيق،اهداف تحقيق ،ساحه تحقيق،معرفى ولايت كابل و معرفى ناحيه سيزدهم بحث شده و در قسمت يِيشينه به اين موضوع كه ״ه كار هاى در رابطه به موضوع و يا موضوعات فرعى تا به حال در اقفانستان و يا كشور هاى بيرونى انجام شده يرداخته شده است .و در قسمت روش تحقيق كه موضوعات حون ساحه تحقيق، اطلاعات و منابع اطلاعات و هم جنان روش تحليل اطلاعات بدست آمده را به بررسى كرفته است.

در فصل دوم اين تحقيق در رابطه به عموميات وتعاريف آتشسوزى، خصوصيات آتشسوزى،انواع آتشسوزى،عوامل آن ،عوامل انسانى و طبيعى بحث شده است و, در قسمت خسارات آتشسوزى نيزصحبت شده است.و در اخير اين فصل در رابطه با راه هاى كنترول آتشسوزى بحث شده است. و در فصل اخير اين تحقيق هيشُنهادات و ماخذ ذكر شده است. كلمات كليدى:-آتشسوزى ،ضد حريق،مراكز تجارتى،سيستم هاى ضد حريق،بررسى 


\section{فهرست عناوين}

صفحهd

$$
\text { عنو ان }
$$

\section{فصل اول}

1 1.1 1.عدمه

2 طر سح منسله 1.2

3 11. 3 اهمبت تحقيق

3 11 أهد.افــن تحقيق

3 1.5 سو الات تحقيق.

\section{فصل دوم}

4

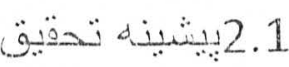
8 (ت 2.2 9 10

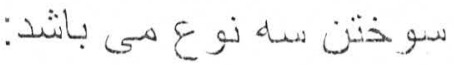

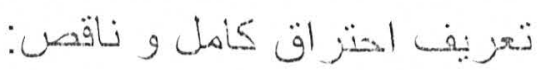

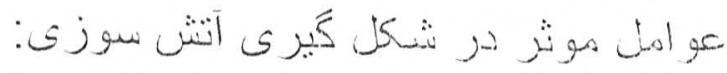
علل آتشن سوزي: حريق هاثى غبر عمده: حربق هاي طبيجحي: حربت هاى عمدى: . 16.

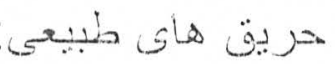
1.3. طبقه بندي انو اع آتش ها: 16 انو الع حريق 17 علت آتش سوزى در جنكل ها: 

بايبز ؛ فصل حريق جنكل هـا: بيمه آنش سوزى: ر عابت نكات ايمنى قبل از وقوع آتش سوزى. 20 نكات ابمنى هذخام وقو ع آتشنسوزى . كيمبا و آنش نشانى. 23 جلوكير ى آتش نسوزى ها: روش) هاي خاموشن ساختن آتش:

\section{فمل سمبوم}

24

24

25

27

28

24

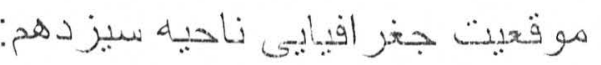
29 (3) 3.2 9. 3.3

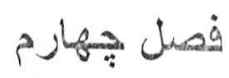

30

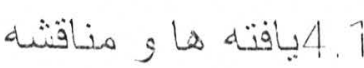

30

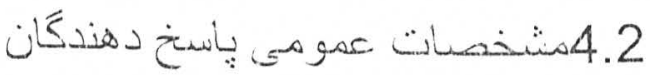

32

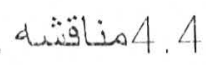

\section{فصلص بينجم}

33 5.1

34

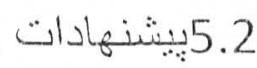




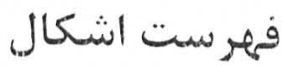

صفحه

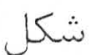

5.

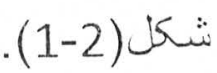

$6 \ldots$ شكل(2-2)مسؤين اطفايه در حال نجات مردم.

6. شكل(2-3)مر مد در حال بر سيى دوكانها..

13. شكل(2-4)مثلث حريق. 16 شكل(2-5) طبقه بندى انواع آثر ها. 16 شكل(6-2) انواع حريق. 23 شكل(2-7) موتر اطفايه. 29 شكل(1-3)نقشه ناحيه 13 شبر كابل.

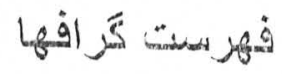

30.

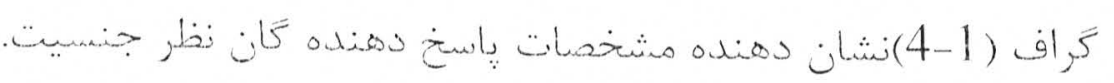
30. كراف (2-4)نشان دهنده مشخصات ياسخ دهنده كَان نظر سن و سطح تحصيل. 31 كَراف (3-4)نشان دهنده آسيب ديدكًان از آتشسوزى 31 كَراف (4-4)نشان دهنده اشخاص كه كَفتند از آتشسوزى آسيب خواهد ديد. 


\section{فصل اول}

1.1 1

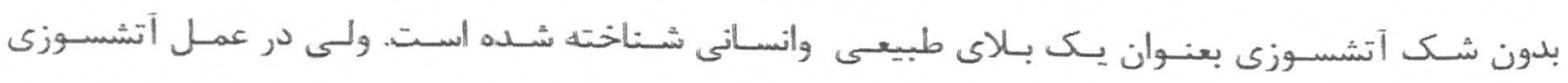
هم از نظر تلفات جانى و همم از نظر خسارات مالى ههيب ترين آفت در جهان دحسوب مى شود.

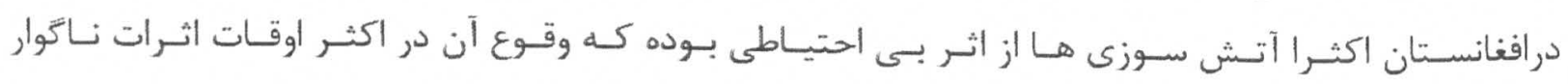

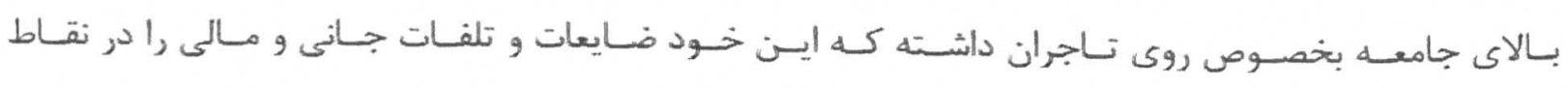
مختلف كشور بالا ميبرد.

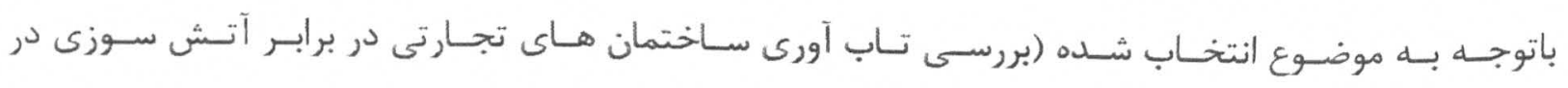
ناحيه باشهر كابل) مشـكلات فراوانسى فـرا راه ايسن تحقيـق وجـود دارد كـه متاسـفانه تـاهنوز در ايسن زمينـهـ

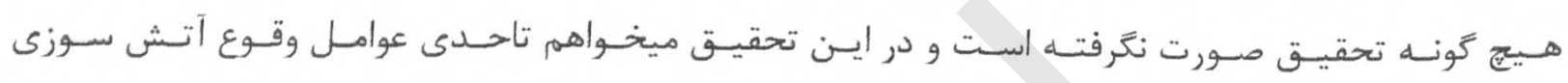

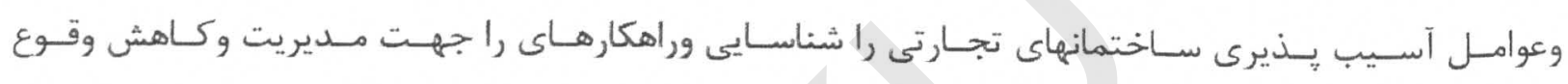

آتش سوزى ارايه بدارم .

عوامل متعدد كه در رابطه بـه وقـوع آتش سـوزى هـاى مـدهش و تشــديد خسـارات آن كـهـ سـبب تخريبـات

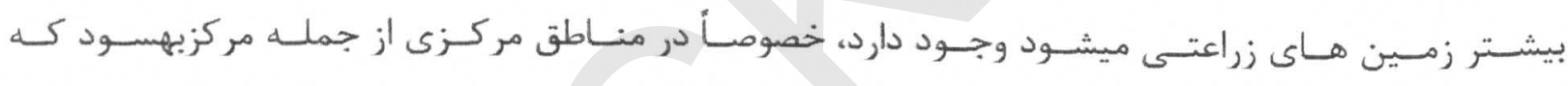

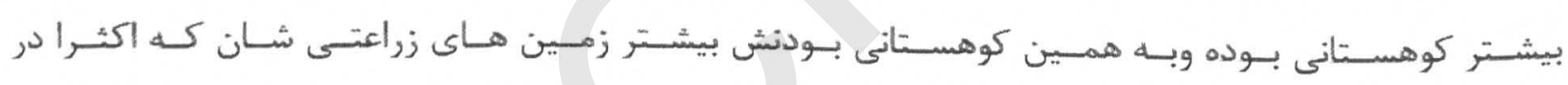

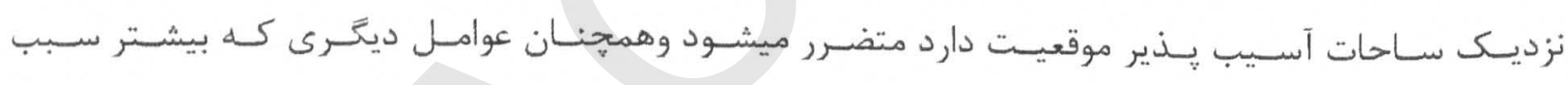
خسـارات زمسـين هـا زراعتـى و جوامـع روسـتايى ميشـود هماتـا تخريبـات منــابع طبيعسى و يوشـش گيــاهى

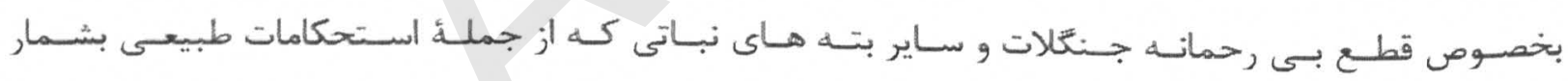
ميروند مى باشد.

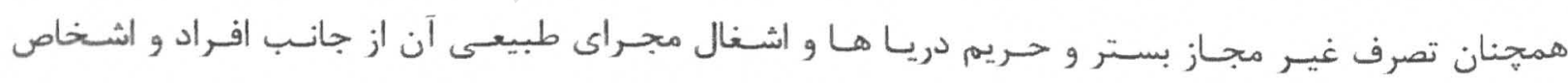

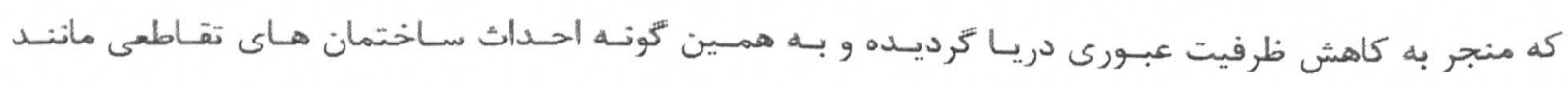

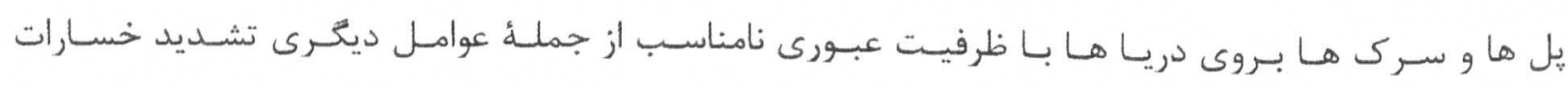
آش سوزى ها در كشور به حساب مى آيند.

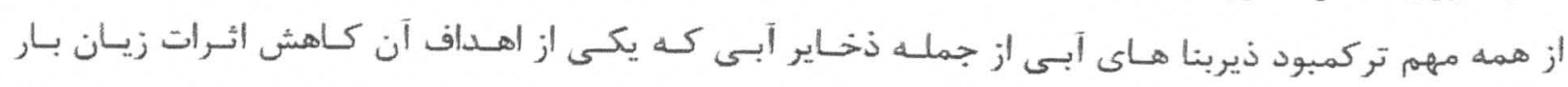

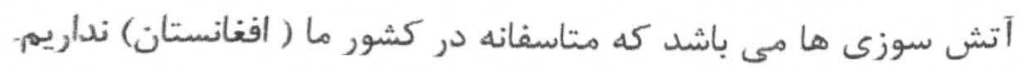




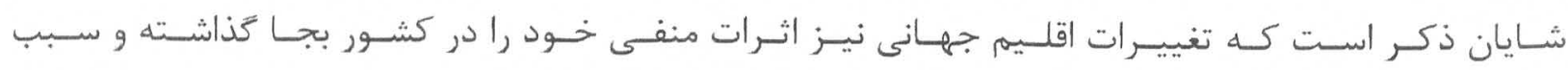

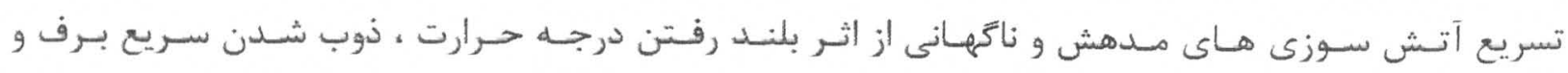
يخ و بارانده تى هاى نابه هنتام در كشور ترديده است.

\section{2 طر ح مسله}

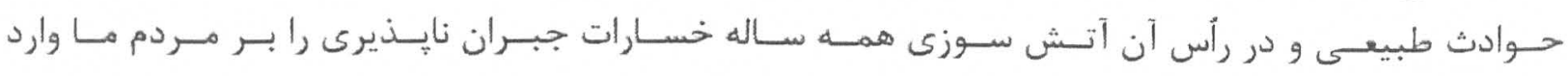
ميكند. كه سـبب از ميـان رفـتن جـان، مـال و معيشـت مـردم شـده، آسـيب يـذيرى مـردم را بـيش از بـيش افزايش مى دهد. وقوع ايسن حسوادث بخشى از فضـاى حيـاتى و محسيط زيست را تحت تـاثير قـرار ميدهـد.

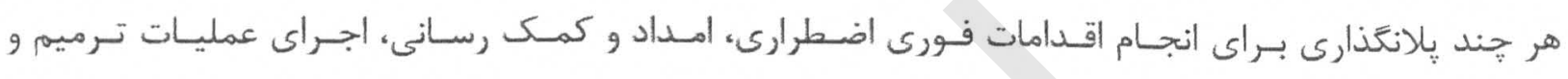

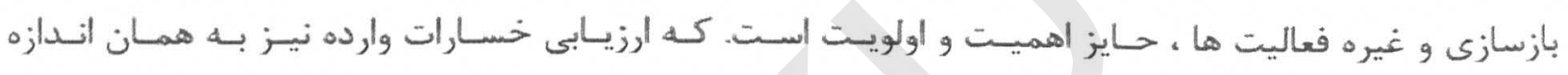
حايز اهميت است. اين تحقيق كه در مـورد ارزيابى آسـيب يـذيرى اقتصـادى ومحيطى آتش سـوزى در ناحيـه باشـهر كابل

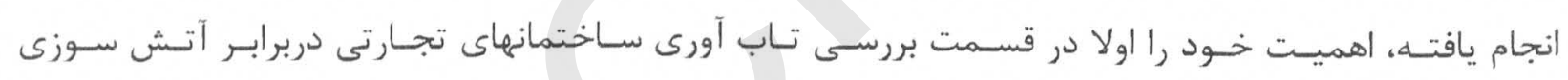
درناحيـهـ 13شـهر كابـل دارد كـهـ معلـوم شـود، سـطح أســيب هـذيرى اقتصـادى ومحيطـى آتـش سـوزى درناحيـه 13شـهر كابـل تـا هـى انـدازه اسـت، ثانيـا ميتـوانيم راه كارهـاى را جهـت مسديريت آتس سـوزى وكـاهش سـطح آسـيب يـذيرى اقتصـادى ومحيطى آتش سـوزى را ارايـهـ بـدارم وهمجنـان ميتـوانيمم مـوارد ذيل را در قسمت تحقيق وارزيابى خود در نظر بيتّريم.

بررسى ساحات آسيب يذير اقتصادى ومحيطى ازآتش سوزى

$$
\text { بر رسى نقش مردم در روش مديريت آتش سوزى برى }
$$

بالابردن سطح آتاهى مردم در قسمت خطرات ومديريت آتش سوزى 
تحقيقى را كه من انجام داده ام از خُندين لحاظ قابل اهميت است اولاً قبلا در رابطه به آتشسوزى در ناحيه 13تحقيقى انجام نشده است بناءٌ مردم اين ناحيه مى تواند براى آماده تى در مقابل آتشسوزى از اين تحقيق استفاده كنند بخاطرى كه تحقيقات نشان داده است حَّونه مردم از آتشسوزى صدمه ديده و خحَّونه آن را محار نموده اند.و همجنان اين ميتواند براى محصلين سال هاى بعد كه تحقيق انجام ميدهند بحيث يك ريفرينس استفاده شود.در اخير اين تحقيق مراكز آسيب بذير از نظر آنشسوزى در اين ناحيه مشخص خواهد شد. وهمجنان مالكين اين مراكز ميتواند راه هاى جلوكيرى را بيدا نموده و آتشسوزى را كاهش دهند.

11.4 اهداف تحقيق

هر تحقيقى نياز به اهداف واضع و روشن دارد كه جهت تحقيق و بررسى موضوع انتخاب شده (بررسى تاب آورى

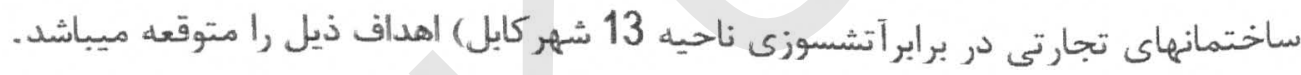

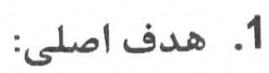

دانستن تاب آورى ساختمانهاى تجارتى دربرابر آتش سوزى در ناحيه با شهر كابل.

2. اهداف فرعى:

دانستن تعداد مراكز تجارتى در ناحيه 13 شهر كابل.

دانستن وضعيت دكاكين در رابطه به آتشسوزى.

1.5

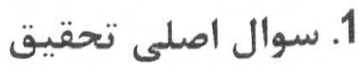

ساختمانهاى تجارتى ناحيه بـ شهر كابل جِى اندازه در برابر آتش سوزى تاب آور استند؟

2. سوالات فرعى تحقيق

1. تا به جِى اندازه ساختمان هاى تجارتى در اين ناحيه متضرر شده اند؟

2. آتش سوزى تا جىى حد به ساختمان هاى تجارتى ميتواند صدمه برساند؟ 


\section{فصل دوم}

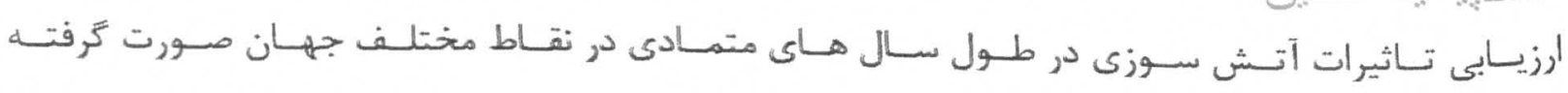
وهمجِنان راهكار هاى جهيت مديرت آتش سوزى بيشكش شده است.

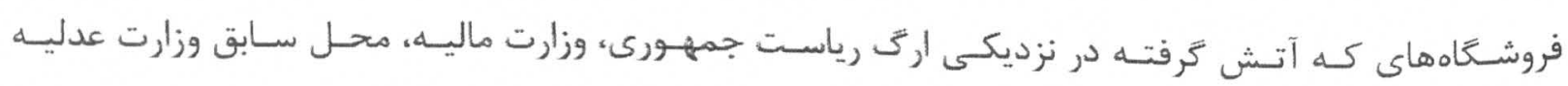

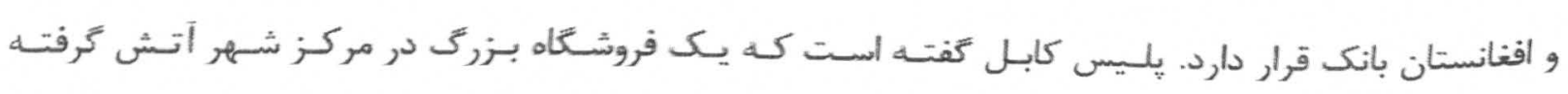

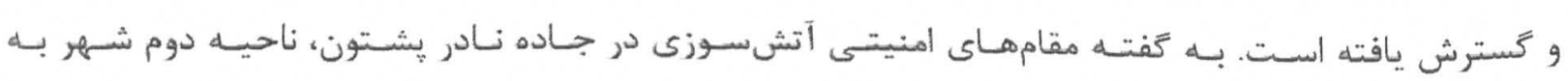
مدت r ا ساعت (8 شام تا 8 صبح) ادامه داشت. آذرخش حافظى، مسوول روابط خـار جى اتاقهـاى تجـارت و صـنايع افغانسـتان بـه بىبىسىى كَفت كـه ايسن آتشسوزى دهها ميليون دلار به صاحبان مغازهها ضر رسانده است.

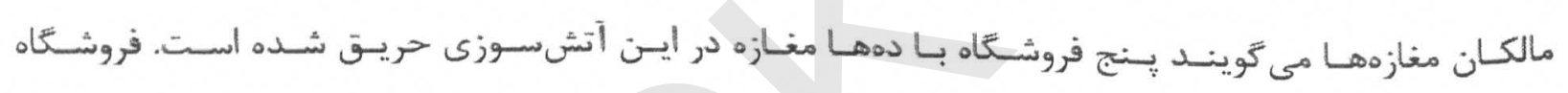
خيرخواه، اتفاق، زرنكار، كابل و صديق عمر از جملهاى اين ماركتهاست.

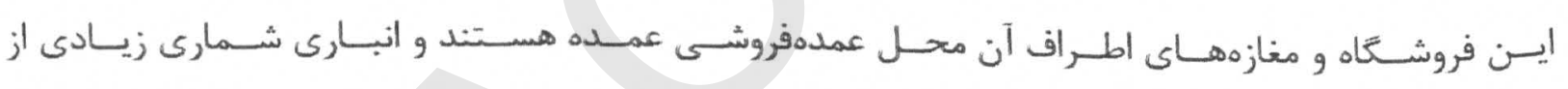

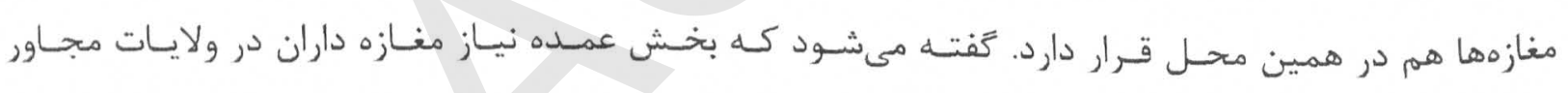
كابل همم از همين فروشكاهها تامين مىشود .

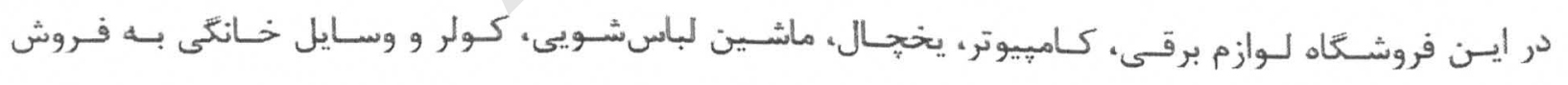
مىرسد.

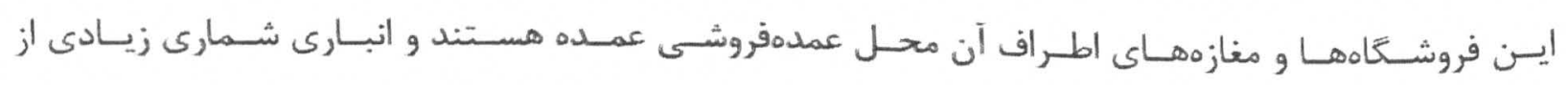
مغازمها همم در همين محل قرار دارد

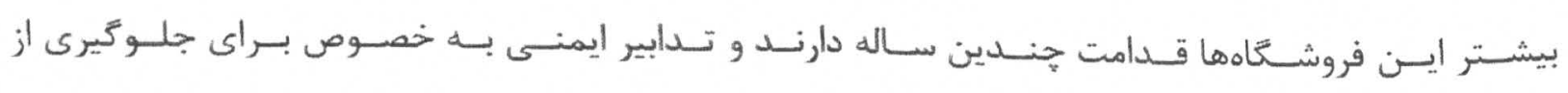
آتشسوزى در آنها صورت نثرفته است 


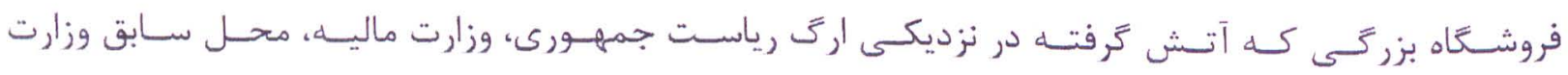
عدليه و افغانستان بانك قرار دارد .اين محل از مزدحمترين مناطق شهر كابل است.

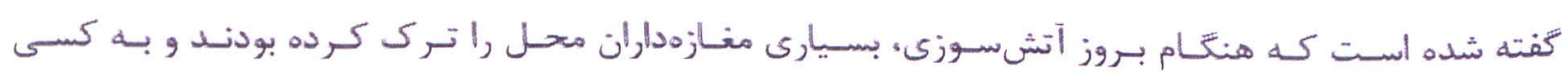

$$
\text { آسيبى نرسيده است. علت آتشسوزى هنوز روشن نيست. }
$$

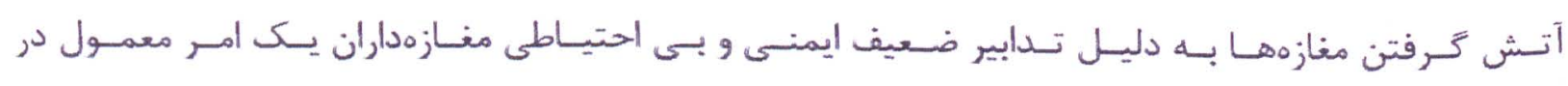

افغانستان است و هر سال خسارات هنكُفتى را به بار مى آورد.

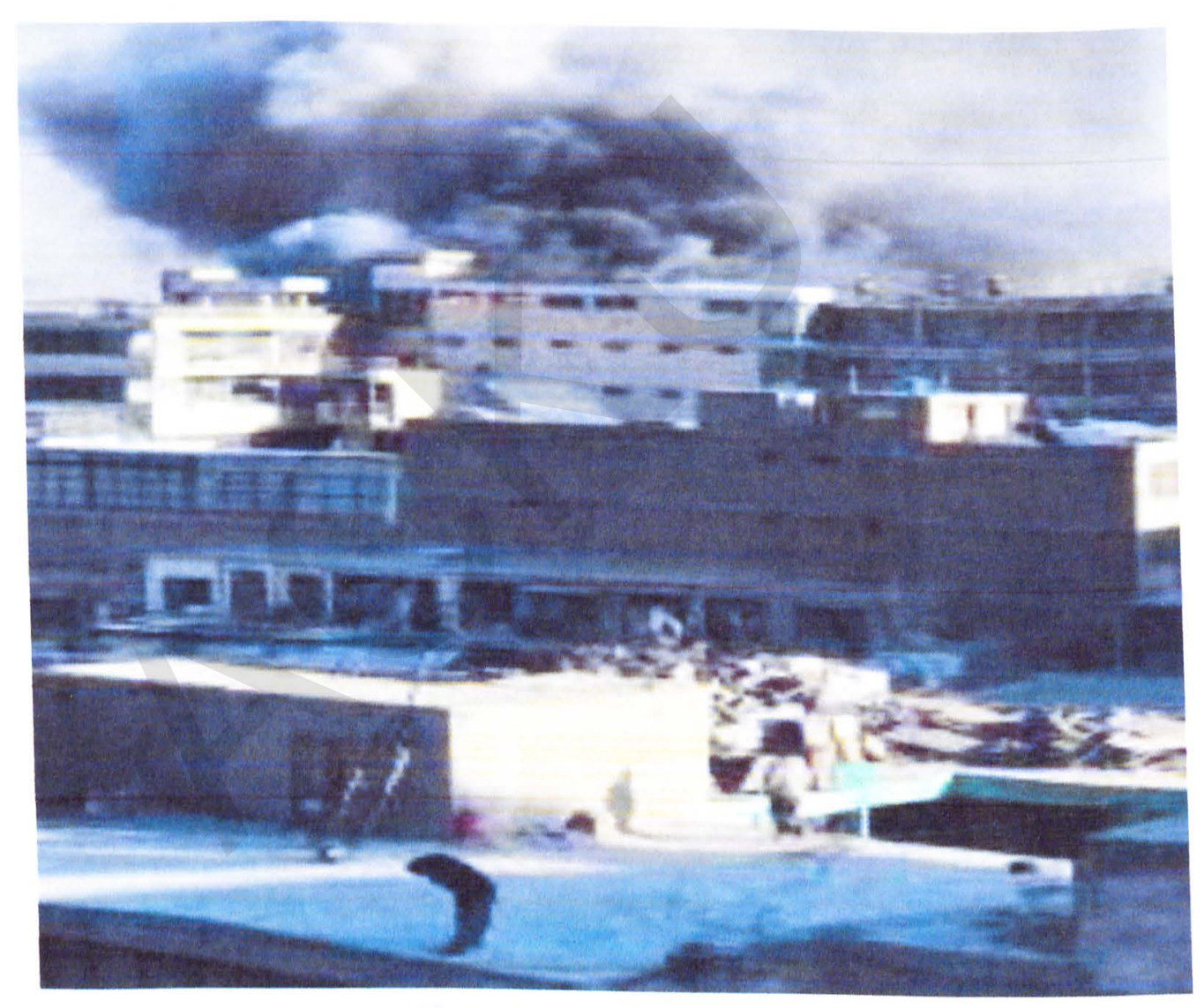

شكلل(2-1) تصوير از يك اتتشنوزى

در دهمم ماه عقرب سـالروان آتش سوزى در مركز خيرخـواه در سـاحه ناحيـه اول شهر كابـل دههيا دكان

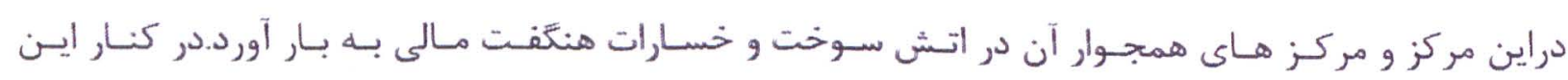

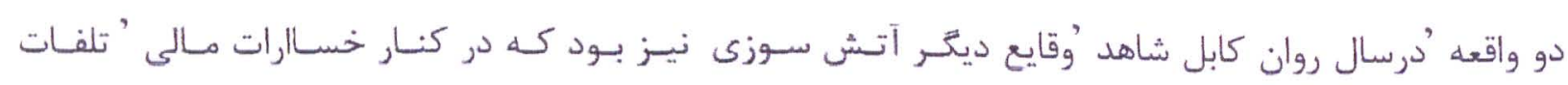

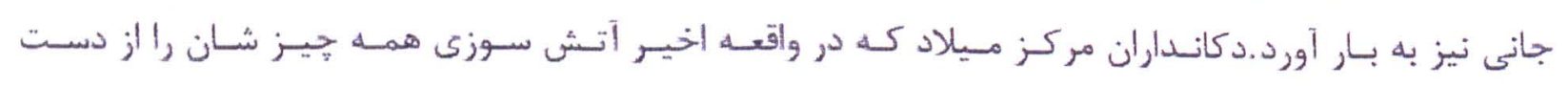


داده اند حرف هـايى دارنـد كـه قابـل مكـث و دقت اسـت. آنهـا ادعـا دارنسـد كـهـ آتش حـوالى سـاعت شـش صبح شعله ور شد.

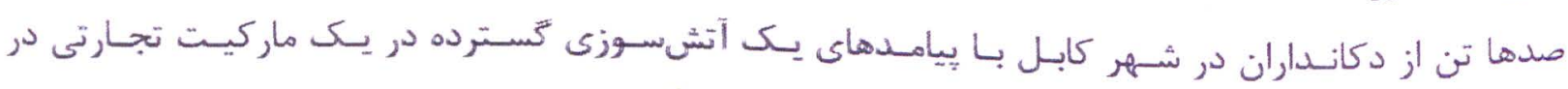

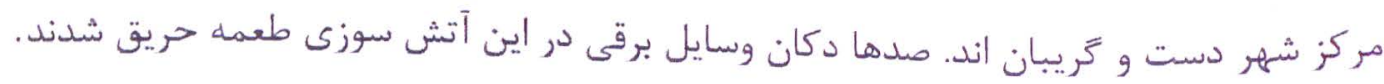
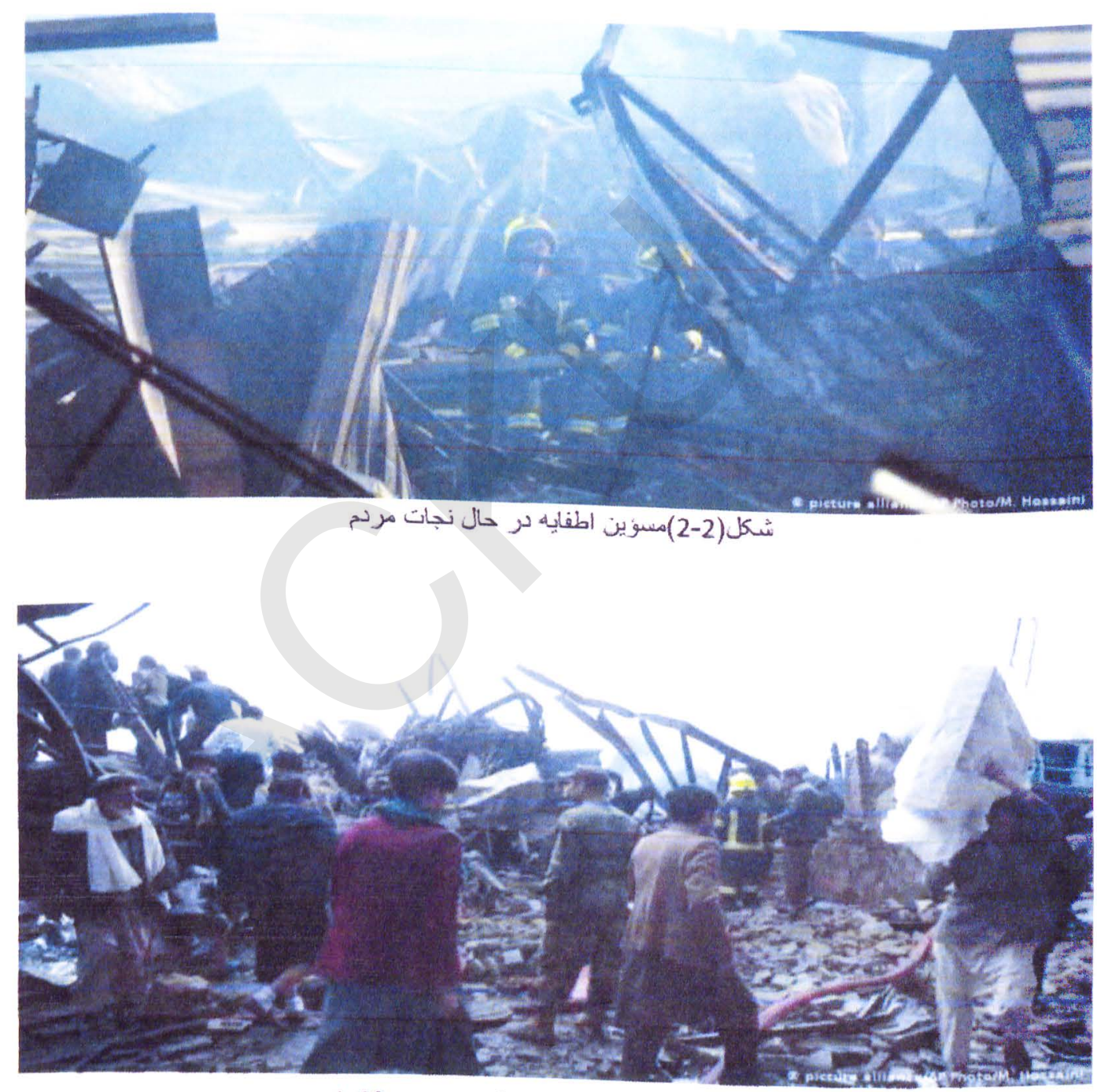

$$
\text { شُكل (3-2)مردم در حال بررسى دوكانها }
$$

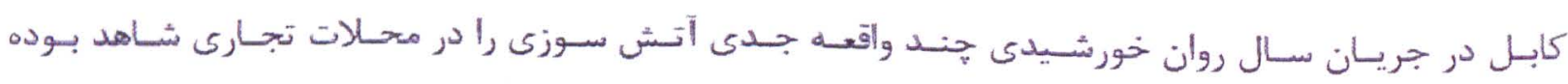

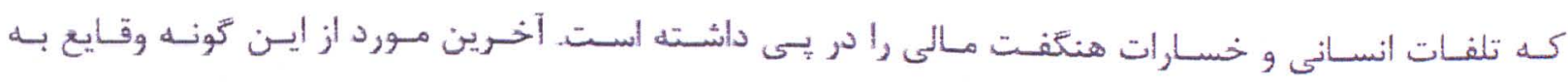




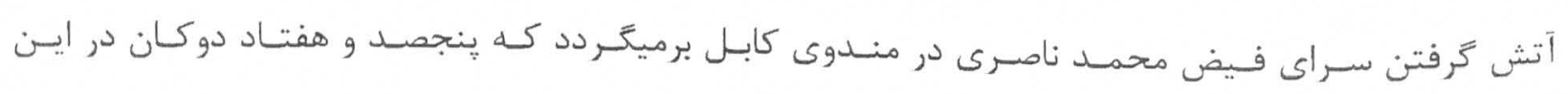
آتش سوزى سوخت و خسارات عظيم مالى را به بار آورد.

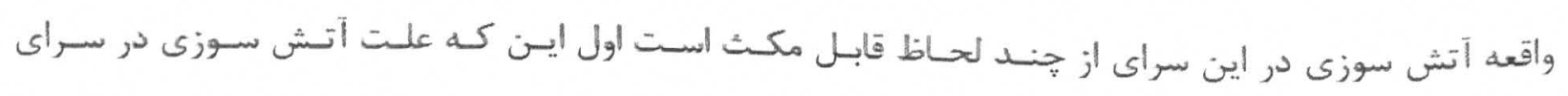

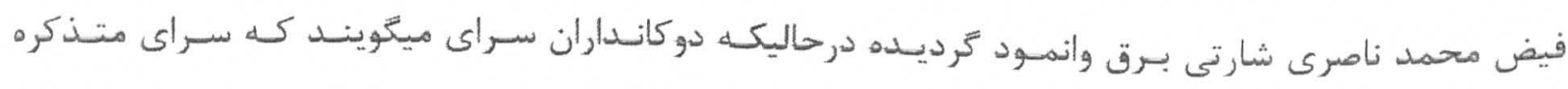
ازريق شب فاقد انرثى برق است.

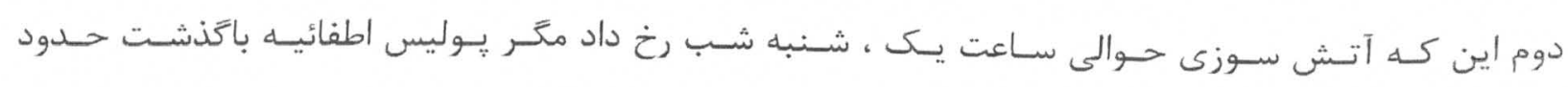
جهمل و هشت ساعت موفق به مهار كردن آتش شد.

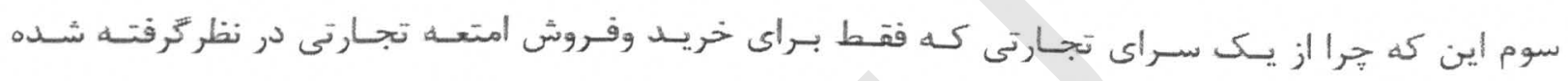

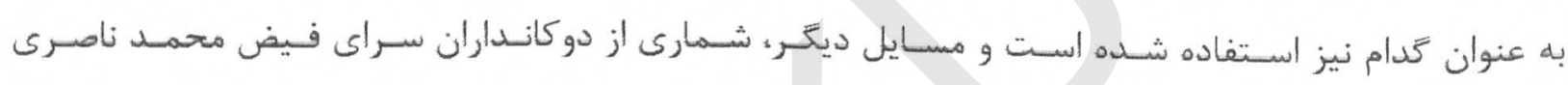

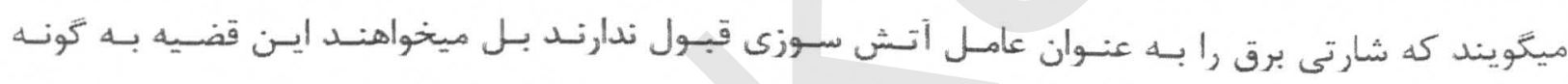

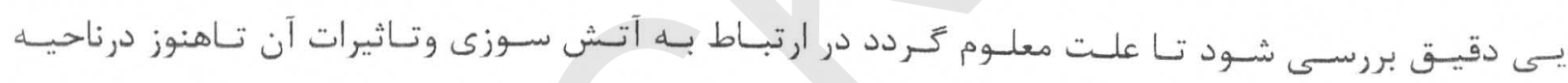
13شهر كابل كدام بر رسى وارزيابى صورت نتخرفته است.

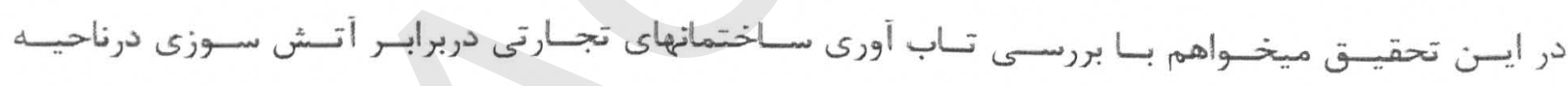

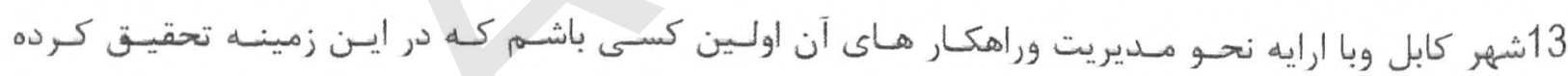
باشم. 


\section{2. (تعار بف و عموهبات) آتش سوزى: - n}

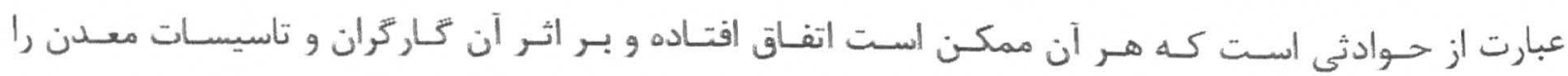
در جِند ساعت بر باد دهــد آمارهـائى كـه در جهـان انتشـار مسى يابـد معـرف خسـارت عظـيم و تلفـات نسـبتاً زياد ناشى از آتش سوزى هاست.

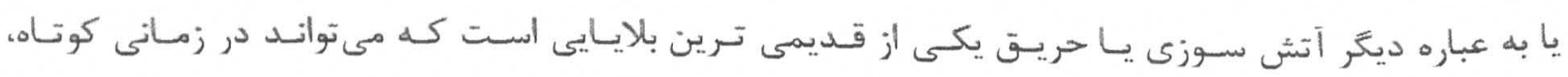
دارايى و سلامتى افراد را به خطر اندازد.

آتشسـوزى يـا حريـق يكى از قـديمىترين بلايـايى اسـت كـه ميتوانـد در زمـانى كوتـاه، دارايسى و سـلامتى افراد را به خطر اندازد. بنـا بـه تعر يـف حريـق عبار تسـت از سـوختن شـديد مـواد سـوختنى يـا آتشـى ناخواسـته و از كنتـــل خـارج شده كه معمولا" با دود و حرارت و نور زياد توام است.

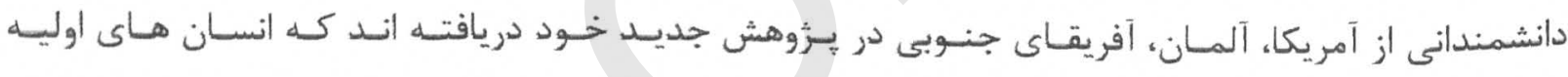

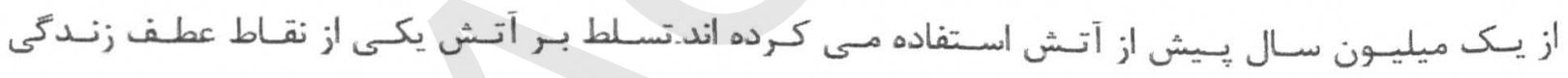

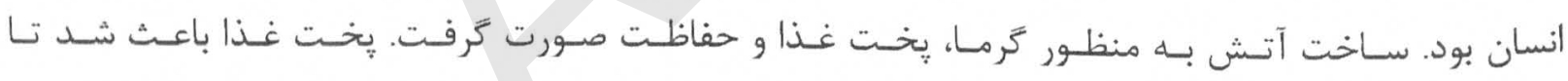
هضم و جويدن غذاها ساده تــــــده و مقـدار انـرزى قابـل دريافـت از مـواد غـذايى افزايش بيابـد كه همـين

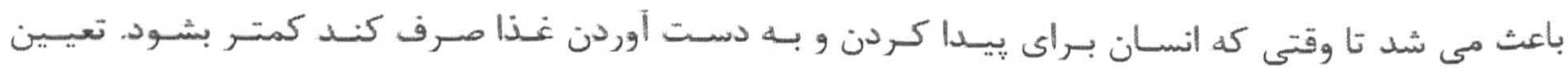
زمان دقيق تسـلط انسـان بـر آتش كـار سـاده اى نيست.شـواهدى از بـر بـا شـدن آتش در بـيش از يـك تـا

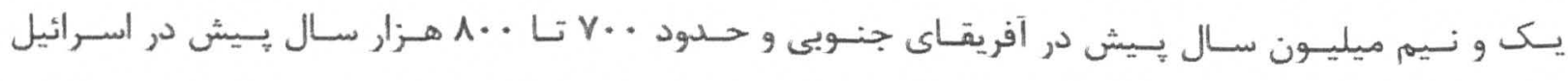
وجود دارد اما با توجه به روباز بـودن ايـن منـاطق ممكن اسـت ايسن آتش هامحصـول صـاعقه باشـندبه ايـن طريق كه زمانى صـاعقه اى باعث بديـد آمـدن آتش شـده و انسـان تـا قبـل از خـاموش شـدن آن آتش بــــ

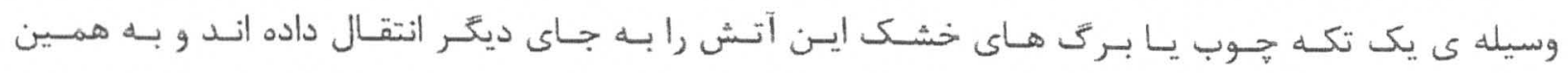




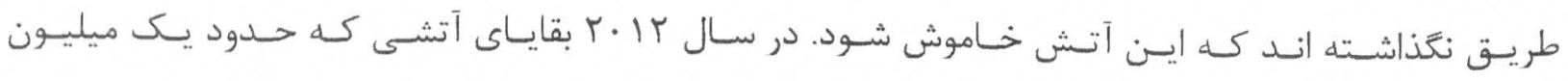

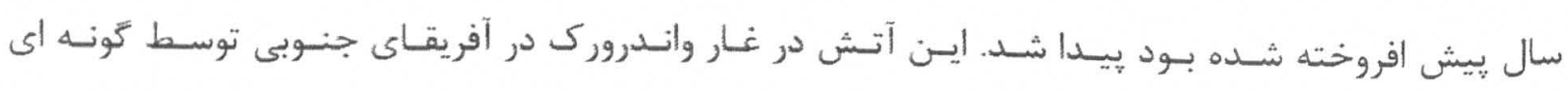

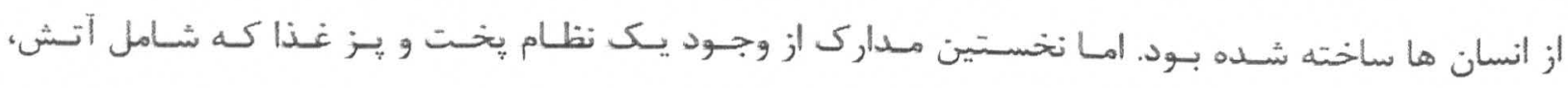

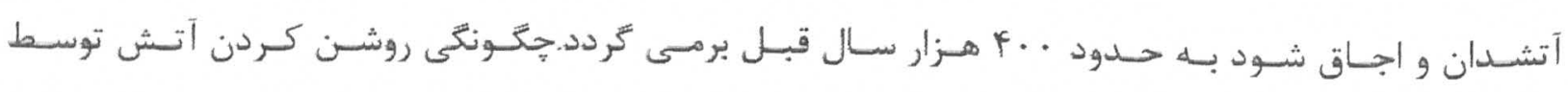

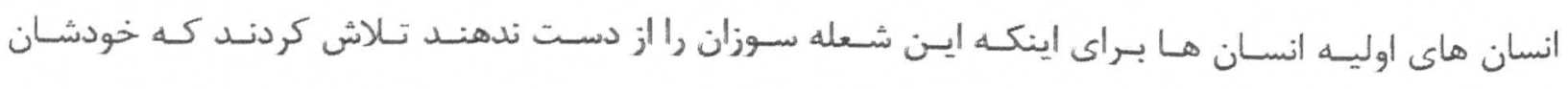

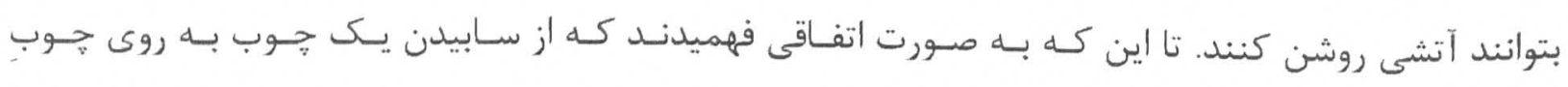

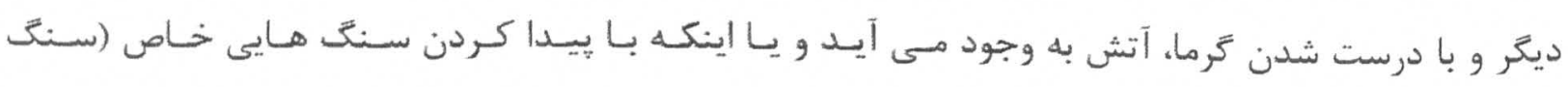

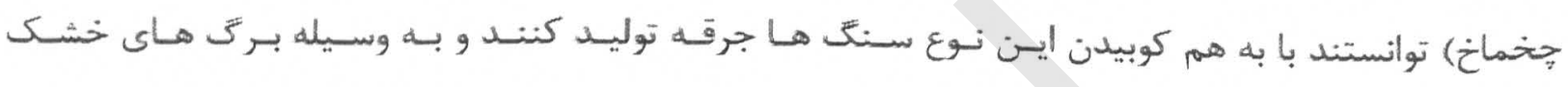
شده اي كه جمع كرده بودند، توانستند خودشان آش درست كنند. بيداكردن غذا توسط انسان هايى اوليه :

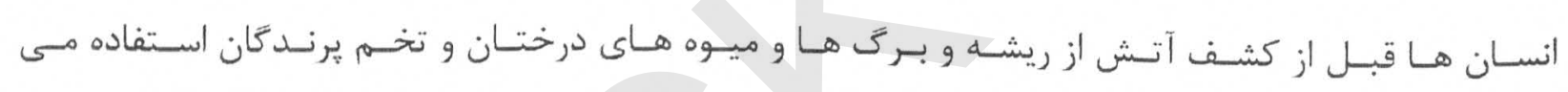

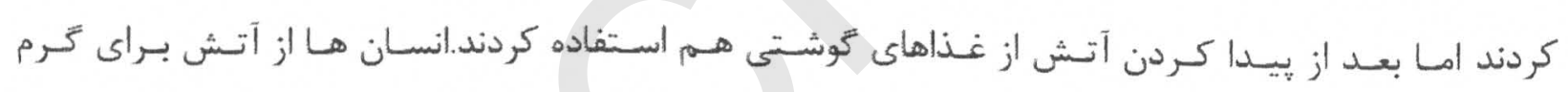

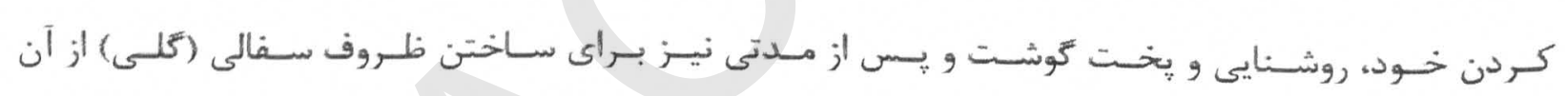
استفاده كردند. تُعريف مر احل احثر اق در آنش نشانى: مراحل احتراق يا هُحونكى سوختن يكى ماده هميشه يكسان و يك شكل نيست. سوخت هاى مختلف نيز هر يك با مشخصات خاص بر توسعه حريق اثر مى كنند اما وضع درجه حرارت نسبت به زمان همواره به اين شكل است كه از نقطه اشتعال آغاز مى شود، به تدريج تحت شرايطى بالا مى رود، با رسيدن به حد نهايى غالبا تا حدودى ثابت مى ماند و يس از كم شدن مقدار سوخت، سير نزولى راطى مى كند. مهام اينجاست كه بالا رفتن درجه حرارت به مقدار سوخت بستكى ندارد و تابع شرايط فيزيكى و شيميايى آن است. مرحله اى كه آتش رشد مى يابد مقطعى حساس است و از لحاظ به كار كيرى اقدامات موثر مبارزه با حريق 
اهميت اساسى دارد. بايد بتوان خيلى زود از وجود آتش مطلع شد تا زمان مورد نياز براى فرار اشخاص و فعاليت ماموران آتش نشانى هدر نرود. براى اين موضوع حتما بايد ساختمان و يا كارخانه به تجهيزات اعلام حريق مجهز شده باشد.

\section{مر احل مختلف احثر اق:}

مر حله 1، اشتعال اوليه: در اين لحظه آتش بروز كرده است.

مرحله 2، رشد آتش: اين مرحله از جند دقيقه تا جند ساعت ممكن است متفاوت باشد در اوايل اين مرحله معمولا سوخت كن مى سوزد و توليد دود و كاز مى كند. مرحله 3، يِشروى شعله: در اين مرحله آتش به اغلب مواد سوختنى سرايت كرده و درجه حرارت سريعا افزايش مى يابد.

مر حله 4، اوج احتراق: آتش به حداكثر شدت خود رسيده و مواد سوختنى به راحتى در حال احتراق هستند. مرحله 5. يس نشينى: سوخت كاهش يافته و در حال از بين رفتن مى باشد حجم آتش كم كم كاهش مى يابد. مر حله 6، نيمه سوختن و دود كردن: زنجيره واكنش هاى خودكار احتراق در حال از هم گسيختن است. مر حله 7. خاموشى: در اين لحظه آتش خاموش شده است.

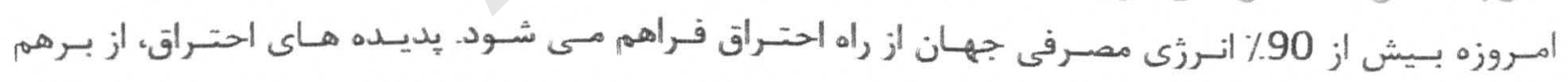

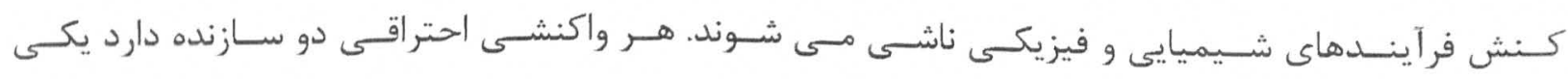
سوخت و ديخَى اكسـنده نـام دارد. مولكـول هـاى سـوخت در اثـر تشعشعات انـرزى حرارتسى شكسـته شـده

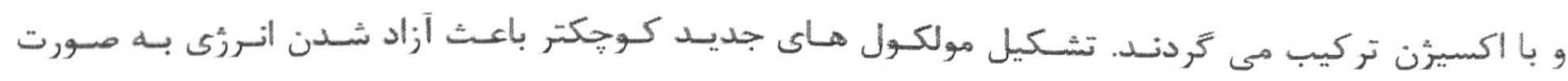

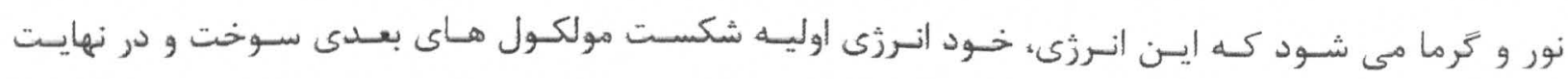
ادامه آتش سوزى مى تردد. 


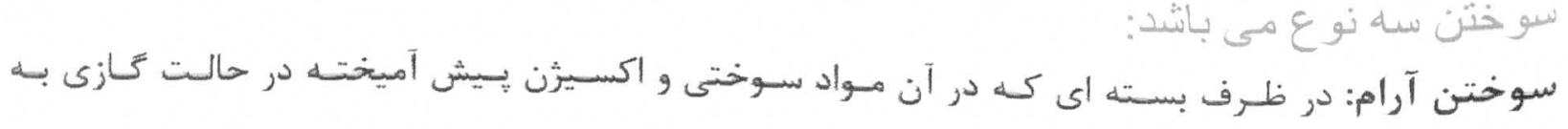

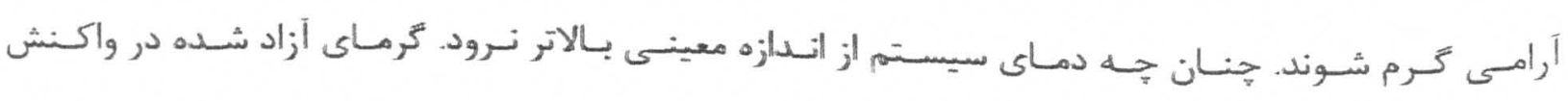

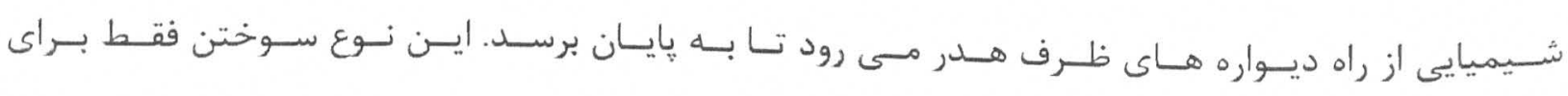
شيميدانان جالب است.

سوختن سرعت متوسـط: بـا كَذشـتن دمـا از يـك حــد بحرانى معينـى، سـرعت واكــش هـا و آزاد شـدن

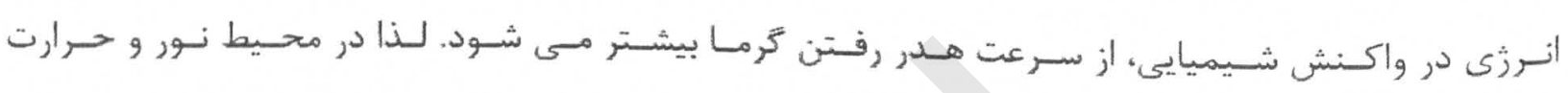
خواهيمه داشت

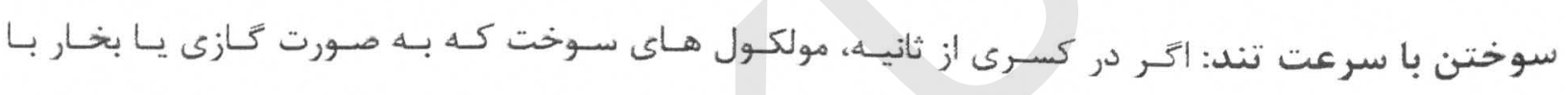

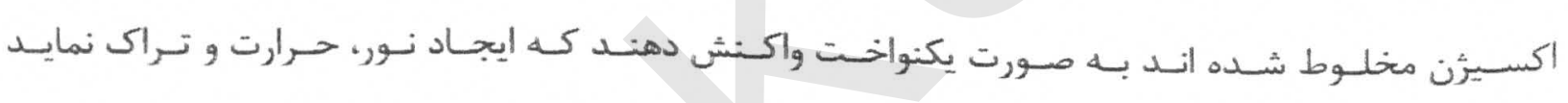

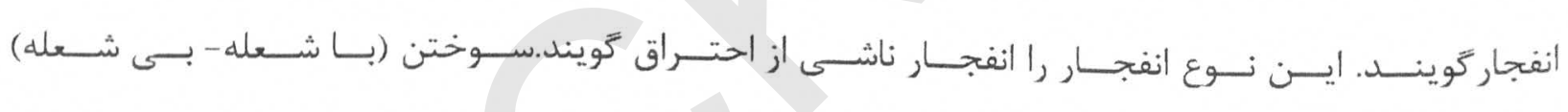
سوختن اكثر مـواد يـك واكـنش اكسيداسـيون حـرارت زا (اكزوترميـك) بـوده و انـرزى حاصـل از واكسنش بـهـ

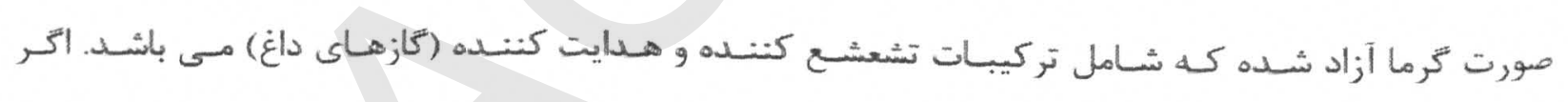

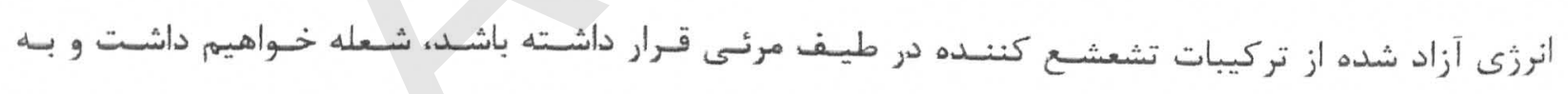

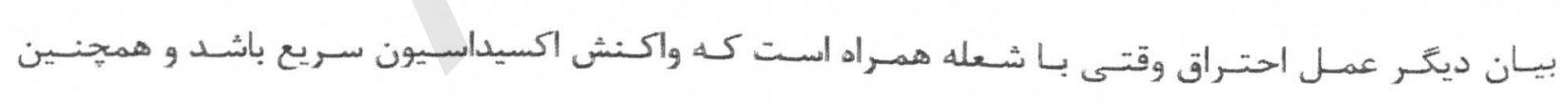
عنصرى كه با اكسيزَن تركيب مسى شـود بـه بخــار تبـديل شـده باشــد و در غيــر ايسن صـورت شعله نخـواهيهم

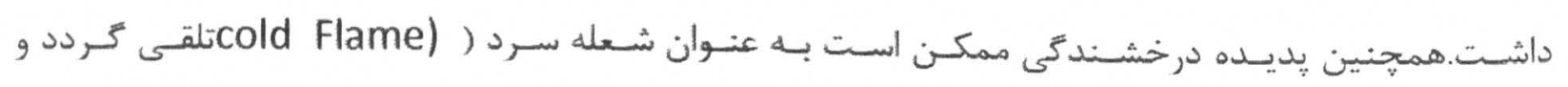

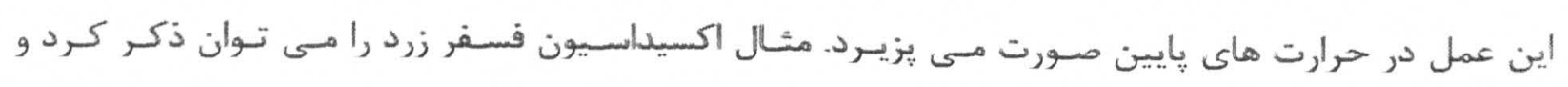

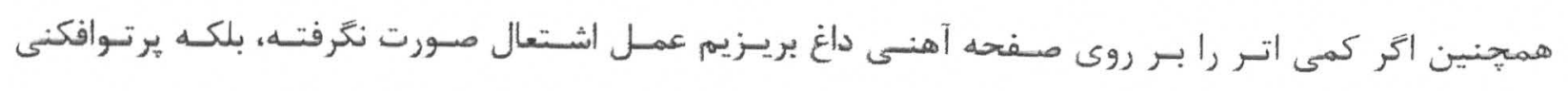
سبز رنك در اتاق مشهود خواهد بود. 


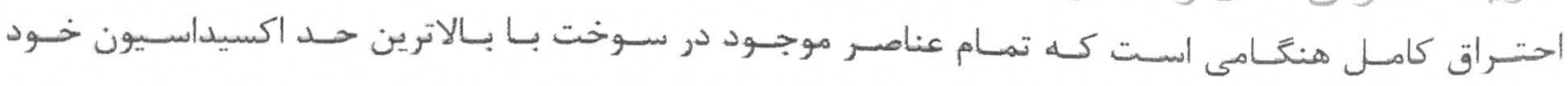

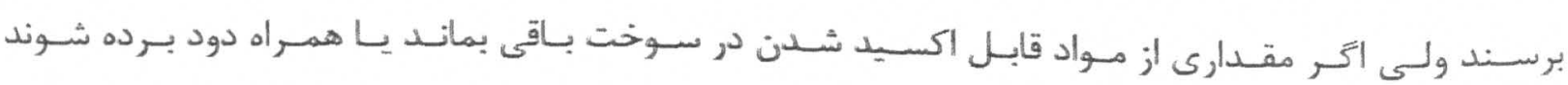

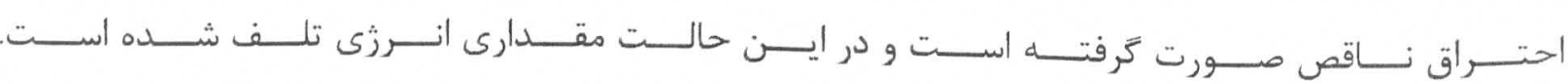

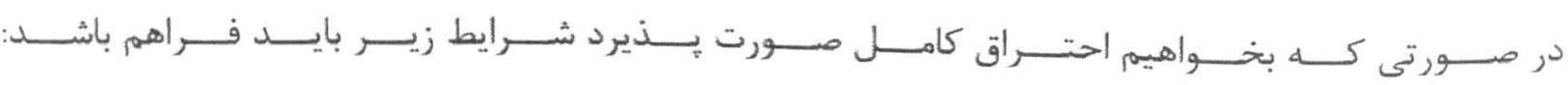
اكسيرن به مقدار كافى جهـت سـوختن فـراهم باشـد. بـراى سـوختن كامـل بايسـ مقـدار هـواى موجسون بـيش از هواى لازم تئورى باشد و اين مقـدار اضـافى بـراى سـوخت هـاى مختلـف متفـاوت بـوده و بسـتخى بـهـ نسوع و جنس و ابعاد سوخت دارد. جهـت سـوخت هـاى جامـد مقـدار هـواى اضـافى لازم 40 تـا 50 درصـد، بـراى سـوخت هـاى مـايع 8 تـا 15 درصـد و بـراى سـوخت هـاى كـازى صـفر تـا 5 درصـد اسـت.ماده قابـل س

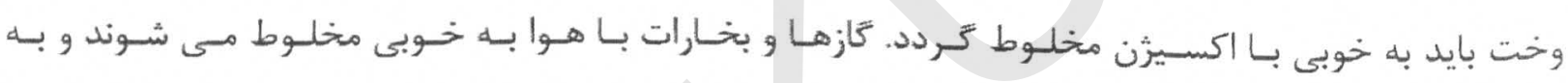

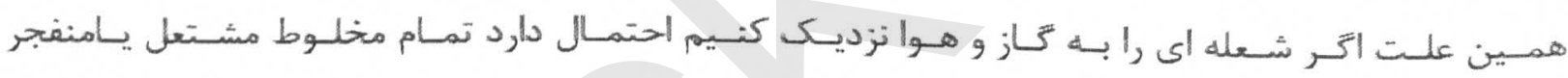
كَردد.مايعات به آسانى گَازهـا نمسى سـوزند محتـرق نمسى شـوند، زيـــا هـوا نمسى توانسد در ذرات آن هـا كـاملا

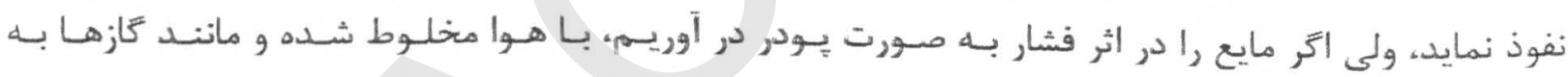

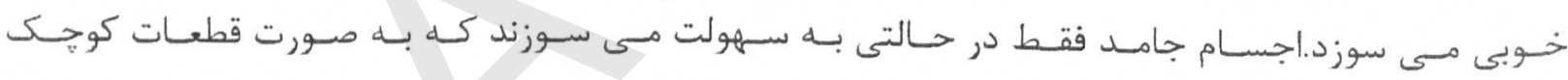
باشـند، يعنى سـطح هـاى آن هـا بـا اكسـيزن هـوا بيشـتر باشـد و اتَـر سـوخت جامـد را بـه صـورت هـودر در

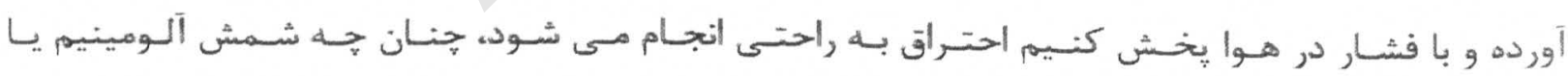
روى و ديكَر فلزات به راحتى آتش نمسى كيرنسد، در صـورتى كـه بـودر ايسن فلـزات بـه راحتسى قابـل اشـتعال مى باشد. انفجار سيلوهاى كندم نمونه اى از اين موارد استـ. 
جند تعريف ديكر:

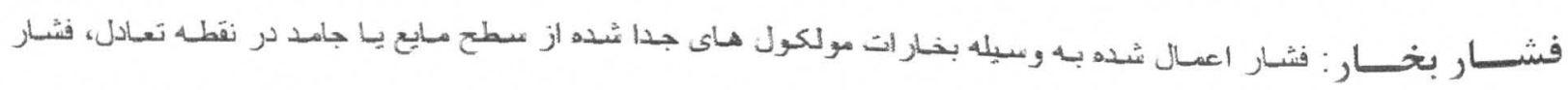
بخار ناميده مى شُود.

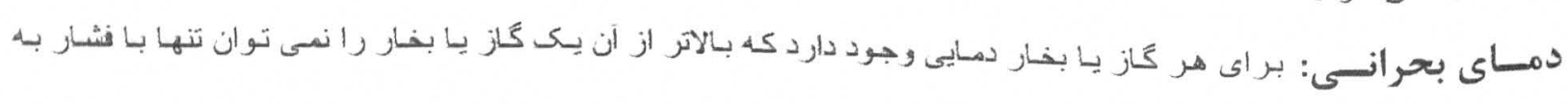

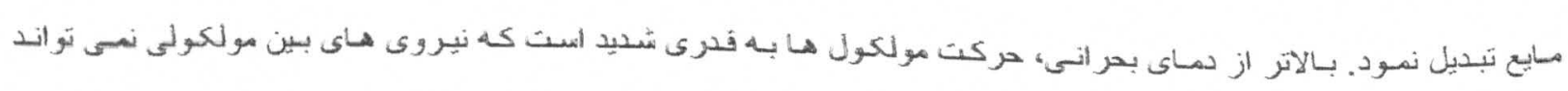
مولكون را مايع نعهدارد. فشار بحرانى: فشار لازم جهت مايع نمودن تَاز يا بخار در درجه حرارت بحرانى راكّيند. نقطه جوش: دمايى است كه فشار بخار برابر فشار جو تردد.

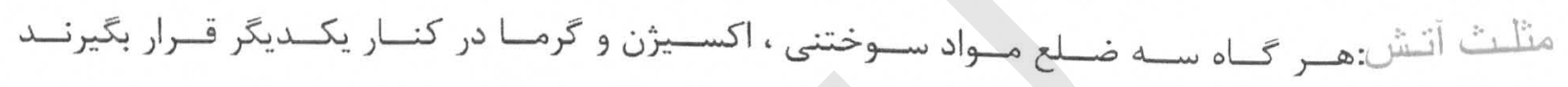

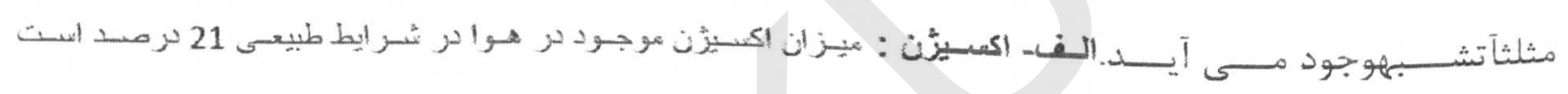
أقرميز أن آن به زير 15 درصد برسد آتش خاموشمى شود. ب - مواد سوختنى :تمام موادى كث قابليـت سـوختن داشـته باشــند مـاده سـوختنى تلقـى مسى شـوند ايسن

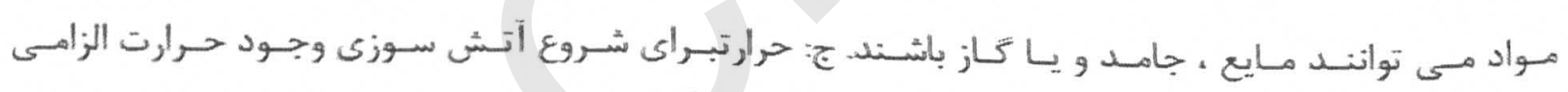

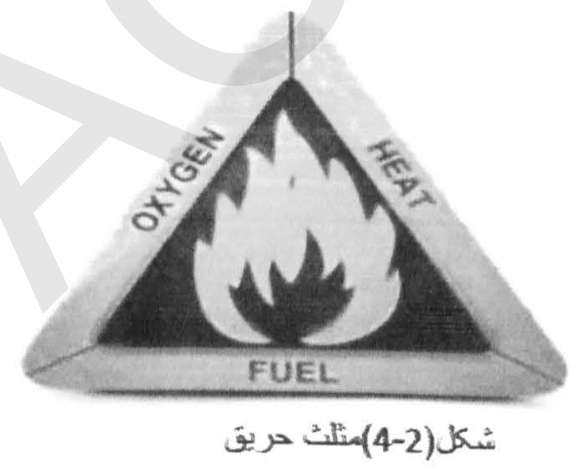

سرعت سوختن و كسـترش شـعله در مـواد مختلف متفـاوت استت. بطـور كلى انـواع مـواد سـوختنى و قابـل اشتعال كه در زندگى روزمره با آنها مواجه هستيد عبارتنداز 1- مواد سوختنى جامد مانند جوب، يارجه،لاستيك 
2- مواد سوختنى مايع مانند فر اورده هاى نفتى، الكل ها

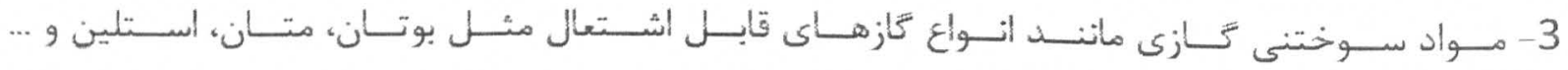

تفاوت انفجــار و آتـشش: تفــاوت انفجـار و احتــاق ناشسى از انـرزى حاصـله نيسـت بلكـهـ تفـاوت ايـن دو

$$
\text { در سرعت آزاد شدن انرزى است . }
$$

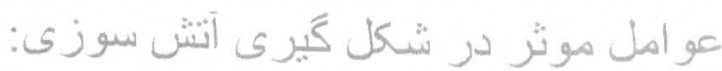

سه عامل در آتش سوزى نقش كليدى دارند. اتر در يك آتش سوزى تنها يكى از اين سه عامل حذف شود آتش سوزى ادامه نمى يابد. اين سه عامل مهمم عبارتند از حرارت، ماده سوختنى و اكسيجن ميباشد. با توجه به شرايط تغيبر يافته زيستى در سالهاى اخير اين مثلث آتش يك ضلع مههم ديخَرى هم كرفته و آن عكس العمل هاى كيميايى در يك حريق است.

مهمترين موضوع در آتش سوزى دانستن علت بروز آن مى باشد. حريق هاى جنّل إز نظر منشاء آنها به صورت علا آنش سوزى: زير طبقه بندى مى شوند.

حريق هاي غير عمده:

حريق هاى طنبيعى: حريق هاى عمدى: حر يق هاى عمدى:

كمبود سطح زمين هاى زراعتى كه باعث محدود شدن ميزان درآمد كشاورزان مى شود و همجنين نداشتن مرتع جهت تعليف دام روستاييان جنتل نشين را وارد مى سازد كه هر ساله با آتش زدن و نابودى به سطح زمين هاى كشاورزى و مراتع خود بيافزايند و يا در اثر تنتَ كردن جنتل ها كه باعث رويش تَياه در عرضه آن مى شود عمل جراى دام را در جنتل بهتر و آسانتر سازند. 


\section{حريق هاى غير عمده:}

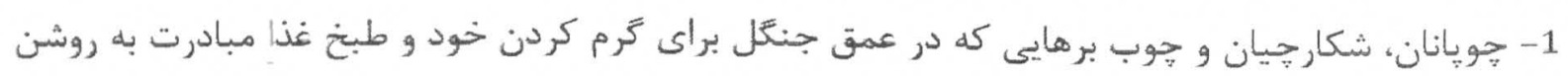
نمودن آتش مى كنيد كُاهى در اثر بي مبالاتى يس ازز اتمام كار آن را خاموش تمى كنتد و در نتيجه إيجاد آتش سوزى مى نمايند. 2- Fاهي از اوقات معتادان به دخانيات ته سيكّار و يا كبريت خاموش نشده را به زمين انداخته موجب بروز حريق مى شوند .

3- شعله هاى خارج شده از كوره هاى زغال، و بى توجهى زغال گيران نيز مى تواند باعث آتش سوزى تردد. 4- آتش زدن بقاياى محصول در مزارع مجاور جنّل مى تواند باعث آتش سوزى جنتل شود. 5- يريدن جرقه از لوكوتيوهاى راه آهن كه از وسط جنكل عبور مى نمايد يا از ساير وسايل نقليه موتورى و با دودكش كارخانجات مجاور جنكل، مى تواند سبب آتش سوزى در جنكل شود.

1- ايجاد آتش سوزى در اثر تخمير و فعل و انفعالات كيميايى مواد آلى زمين. 2- كَاهى از اوقات در اثر صاعقه در جنَّل توليد آتش سوزى ميشود. 3- فوران كوه هاى آتشفشان: در جند سال قبل فوران كوه إتشفشان در كنيا واقع در آفريقاى شرقى باعث حريق شديدى در جنظكل گرديد.

4- تابيدن نور خورشيد به قطعات ته بطرى و شيشه مى تواند مانند عدسى ( ذره بين ) حرارت خورشيد را بر روى گياهان و برى هاى خشك مجاور متمركز و توليد آتش سوزى نمايد. 1.1 - عوامل بوجود آورنده آتش شامل: مواد قابل اشتعال، حرإت و اكسيجن (هوا) كث از تشكيل إين عوامل مثلثى بث نام مثلث آتش بوجود مى آيد. 


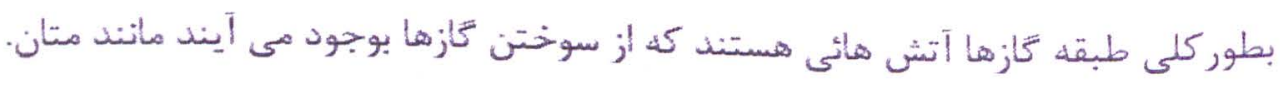

1.3. طنقةه بندى انو اع آتش ها:

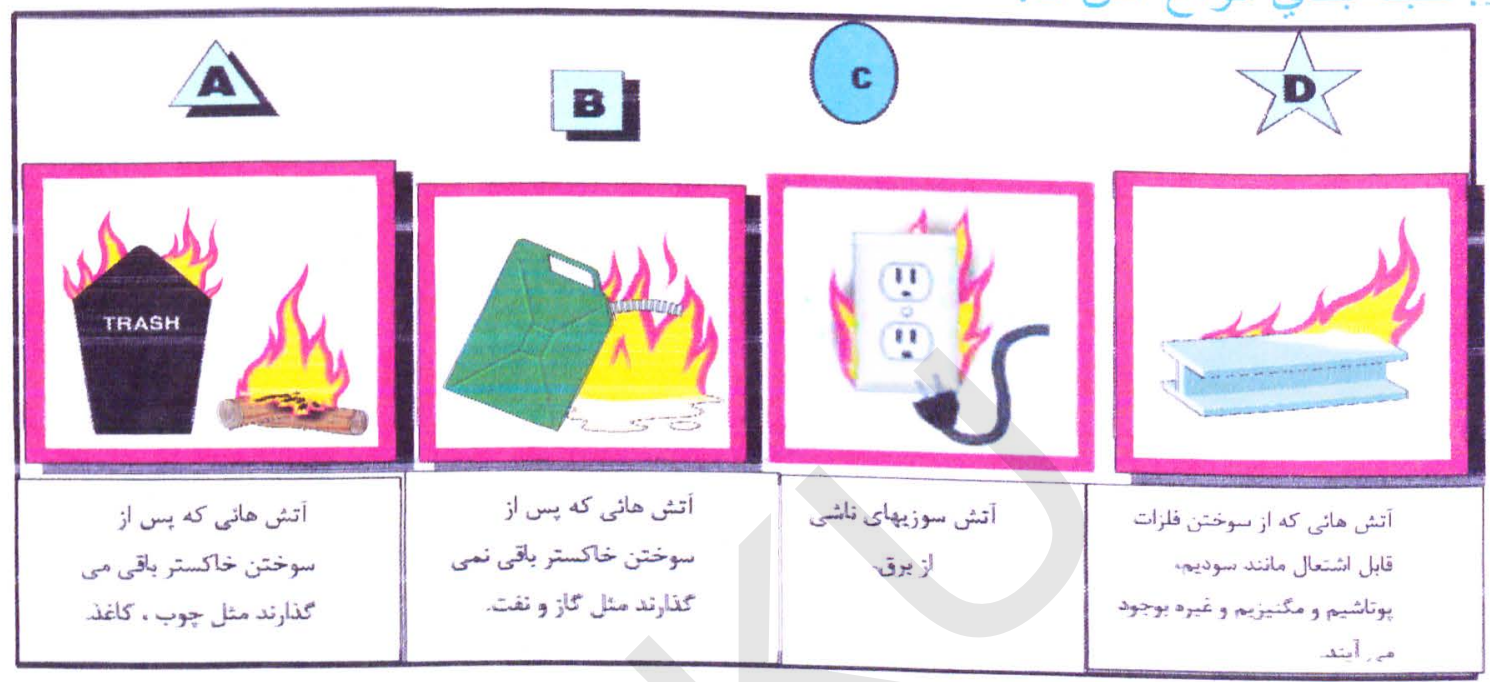

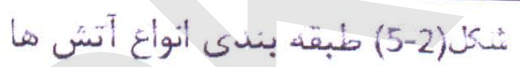

انواع حريث

ل آتش كيرى منازل ل ل ل ل
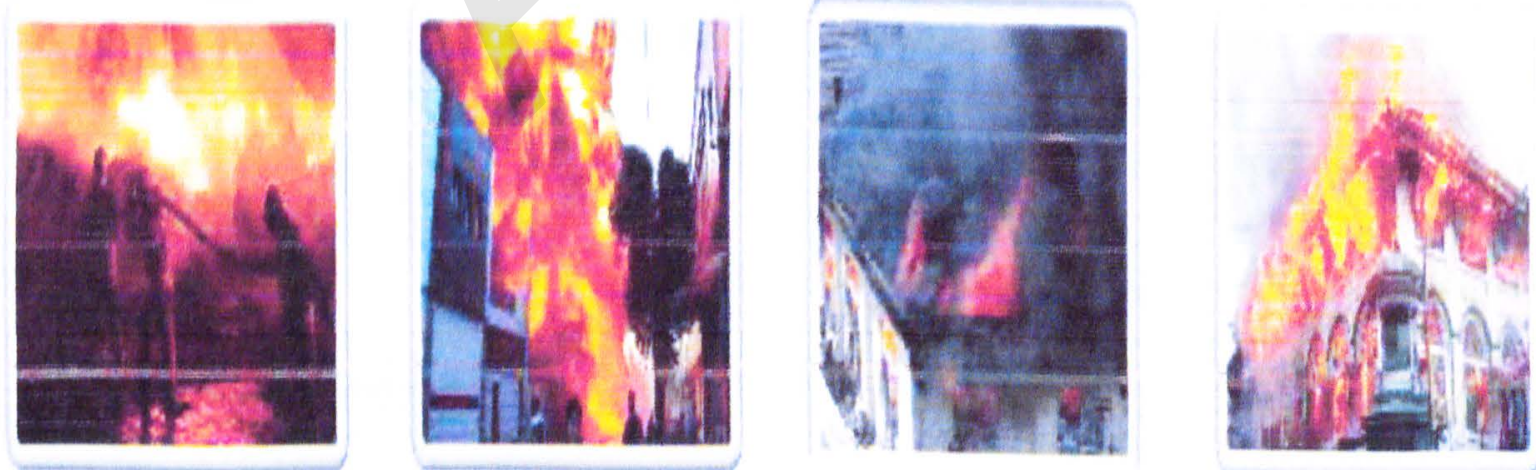

شكلم|(2-6)انواع حريق 
آتش سوزى در جنَّل بخاطر موقعيت مناطق جنتلى كه اغلب محيطى باز مى باشد، بصورت آزاد و بدون اينكه با مانعى برخورد كند انتشار بِيدا مى كند و به هر طرف بِيشرفت كرده و در جهت هاى مختلف آتش سوزى ادامه

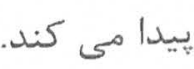

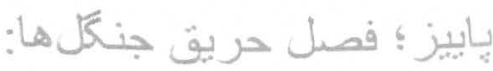

بركَهاى خشك و وزش باد به خودى خود خطرى براى جنتّل به حساب نمى آيد، ولى وقتى آتشى در دل

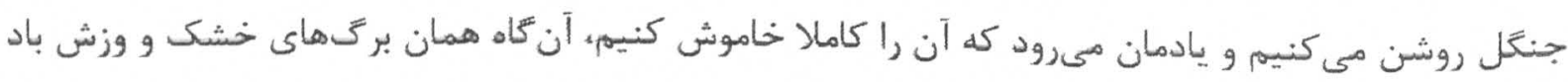
ميتواند جنكل را به تلى از خاكستر و دود تبديل كند.

به همين دليل است كه به كَفته كارشناسان حفاظت محيط زيست، پاييز را بايد خطرناى ترين فصل براى جنكل هاى كشور به حساب آورد؛ فصلى كه همواره بيشترين حجم تلفات زيست محيطى رابراى جنكَل هاى

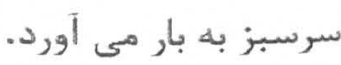

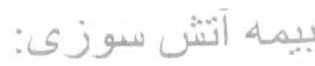
آتش موهبتى است المهى كه كشف آن كام انسان را شيرين نموده و آينده أى روشن و بيشرفته را نويد داد و دريجه اى به سوى زندَّى بهتر را در برابر بشر گُشود. سركشى همين آتش و ديخًر بلاياى طبيعى به عنوان همر اهان قديمى انسان ، همواره مخل آرامش و مانع آسايش بوده، جان و مال و دست رنج زندگى را به نابودى كشانده است. با توسعه اجتماع و تكامل روابط اقتصادى و ثسترش فعاليت هاى صنعتى ، تواتر و شدت وقوع حوادث آتش سوزى افزايش و اهميت آن براى واحدهاى تجارى و بنتاه هاى اقتصادى بعنوان يك تهديد بالقوه نمايان كَشته است. آتش سوزى ، صاعقه ، انفجار ، زلزله ، ، طوفان و ... أز جمله بلايايى هستند كه حتى با اعمال تدابير بِيش گَير انه و مراقبت، ممكن است ماند فاجعه آتش سوزى بزرگ لندن، زلزله بزرگ توكيو، بوئين زهرا، رودبار، بمم كرمان و .... حاصل يك عمر تلاش و كوشش انسان ها رالز بين ببرد. 
رعايتت نكات ابمنى قبل از وقوع آتش سوزى إنى - اصل دورى مواد قابل اشتعال از وسايل آتش زا را دادر تمام تأسيسات و مكان هاى مسكونى و حتى معابر عمومى رعايت كنيد. - در ساختمان ها درهاى خروج اضطرارى بِيش بينى كنيد و وسايل اطفاى حريق را كنترل كنيد. - حداقل دو راه براى خروج اضطرارى از ساختمان تعيين كنيد. - مكانى را در خارج از خانه تعيين كنيد تا، بعد ازت تريز، يكديتُ را در آنجا بيابيد. - برنامه خروج اضطرارى و كريز از آتش را حداقل دو بار در سال تمرين كنيد. - حتماً، هنتام خروج از محل، شير اصلى ورودى تَاز به ساختمان را ببتديد. - براى باخبر شدن از آتش سوزى احتمالى، از آشكارگَرها (دود، حرارت يا شعله) استفاده كنيد و نسبت به نصب آن در منزل دقت لازم را به عمل آوريد.

- كيسول آتش نشانى مناسبى در منزل داشته باشيد و در مورد نحوه استفاده از آن، آموزش ببينيد و به أعضاى خانواده نيز آموزش دهيد. در ساختمان هاى بزرك از سيستمم خاموش كننده اتوماتيك استفاده كنيد. -از انباشتن مواد آتش زاه به ويرُه در نزديكى منابع حرارتى، خوددارى كنيد. - از نتمعدارى مايعات و تازهاى قابل اشتعال در منزل خوددارى كنيد. در صورت لزوم اين مواد را در ظروف خاص خارج از ساختمان قرار دهيد. - وسايل برقى و اتصالات آنها را به دقت كنترل كنيد تا از استاندارد بودن آنها مطمئن شويد. - به محض مشاهده سيم هاى لخت، آنها را ترميهم كنيد. - در اين باره با هم بحث و تمرين كنيد كه جِّونه در هنَّام آتش سوزى منزل را ترك خواهيد كرد و در صورت لرزم هُخونه از ديخران كمك مى تَيريد و يا به آتش نشانى خبر مى دهيد. - در ساخت و انتخاب محل سكونت خود و خانواده تان ايمنى ساختمان در برابر آتش سوزى، شامل نوع مصالح ساختمانى، اسكلت ساختمان و اجزاى ساختمانى بنا را مورد توجه قرار دهيد. هوب و عايق ها، مواد يلاستيكى، 
فايبر كَلاس و نظير آنها قابل اشتعال هستند، فلزات، گَج و شيشه دير اشتعال هستند و شن، خاك، سنَّ و آجرنسوز غير قابل اشتعال هستند. - خانة، خانواده و اموالتان را در برابر آتش سوزى بيمه نماييد. برنامهريزى كنيد و آماده باشيد (جك ليست) آتش سوزى يكى از حوادثى است كه بيش از هر حادثه طبيعى ديثر موجب مركى مىشود. با رعايت نكات ايمنى قبل، حين و بعد از وقوع آتشسوزى مىتوانيد خسارتهاى مالى و جانى حادثه را كاهش دهيد. همراه با اعضاى خانواده دور هم جمع شويد و در مورد جِكَّنَى انجام اقدامات لازم به شرح زير، قبل و هنَّام وقوع آتشسوزى، با همم مشورت كنيد.

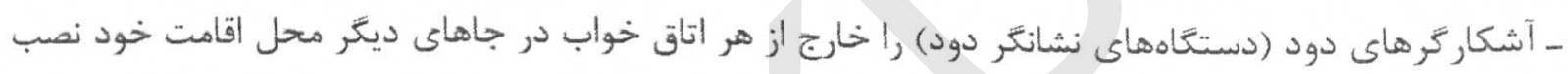
كنيد و باترىهاى جديد در دسترس داشته باشيد براى باخبر شدن از آتش سوزى احتمالى، از آشكاركرها (دود، حرارت يا شعله) استفاده كنيد و نسبت به نصب آن در منزل دقت لازم را به عمل آوريد.

ـ آشكار كرهاى دود را هاهى يك بار امتحان كنيد. نمودارى رسمم كنيد وبعد از انجام آزمايشهاى هر دوره روى آن علامت بكذاريد ـ به كيسول آتشنشانى خود توجه كنيد. مطمئن شويد كيسول آتشنشانى به اندازه كافى ير شده است. از درجه يا دكمه آزمايش استفاده كنيد. اگتر فشار دستخاه كم يا دستَّاه خراب است آن را تعويض و يا تعمير كنيد. در مورد نحوه استفاده از كيسول آتشنشانى آموزش ببينيد و به اعضاى خانواده و دوستان نيز آموزش دهيد. - محلى أمن در خارج از خانه يا محل زندَّى انتخاب كنيد تا، بعد از تريز از آتش، يكديكّر را در آنجا ببينيد. ـ تصميم بخيريد خانواده به هنخام تخليه كجا بروند. تمرين تريز از آتش را حداقل دو بار در سال انجام دهيد. 


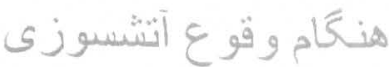

ـ سرعت عمل هنكام روبرو شدن با آتشسوزى، براى نجات جان خود و مصدومان احمالى، كاملاً حياتى است. همان طور كث مى دانيم آتش خيلى سريع انتشار مى يابد، بتابراين بلافاصلد آتشنشانى و الوررانس راخبر كنيد و تا آنجا كه مى توانيد، اطلاعات كاملى در مورد بروز حادثه به آنها بدهيد. - سعى كنيد كه افراد رالز ساختمان بيرون ببريد. - با رعايت جوانب احتياط به خاموش كردن آتش بيردازيد.

- براى نجات جان مصدوم از اتاق آتش ترفته اى كه در آن بسته است بايد قبل از ورود، با لمس در اتاق، حرارت را بسنجيد. التر داغ باشد وارد اتاق نشويد و اتكر داغ نباشد، قبل از ورود به اتاق خند نفس عميق بكشيد تا خون شما بر اكسيزن شود. سيس با شانه خود از بهلو به در ضربه بزنيد. آن را باز كنيد و در همين حال صورت

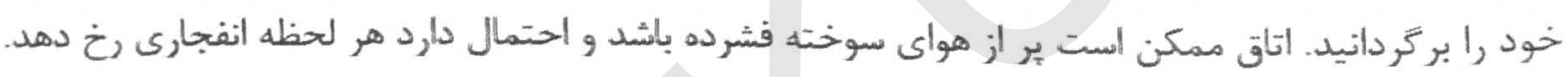
اكر دود كاملاً متراكم باشد روى زمين سينه خيز برويد زيرا با توجه به اين كه هواى داغ بالا مى رود، ممكن است لايد اي از هواي تميز در كف اتاق وجود داشته باشد. - به هيج وجه وارد ساختمان آتش كرفته نشويد مكثر آن كه مجهز به ماسك تنفسى باشيد و كاربرد آن را بدانيد. ـ اكر به هر دليل ناجار هستيد وارد اتاق ير از دود شويد ابتدا مطمئن شويد جانتان به خطر نخواهد افتاد. ـ قبل از فرار از اتاقى كه در آن بسته است، در را لمس نماييد. التر در داغ باشد از خروجىهاى ديكّر استفاده كنيد.

ـ اكر در ساختمان آتش ثرفته كرفتار شدهايد فوراً به اتاقى كثة داراى ينجره است برويد و در را ببنديد. سيس يتو يا فرش را طورى زير در قرار دهيد كه دود وارد اتاق نشود و آن ثاه، از طريق ينجره، تقاضاى كمك كنيد. ـ اكر دود،، حرارت يا شعلههاى آتش مسيرهاى خروجى شما را مسدود كرده است در را ببنديد و در اتاق بمانيد.

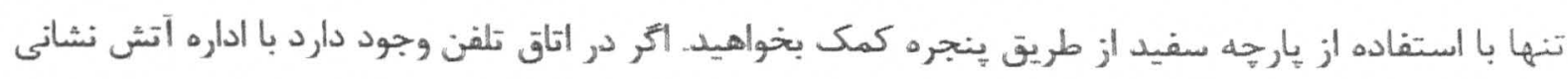
تماس بخيريد و موقعيت خود راخبر دهيد. 
- زمانى كه در جريان حريق واقع مىشويد، با حفظ خونسردى تمام تهويههاى ساختمان را خاموش كنيد تا به اين ترتيب از ورود اكسيثن به داخل ساختمان جلوتيرى شود. - در صورت امكان فوراً مواد سالهم و قابل استفاده رالز محل خارج كنيد. ـ امدادكران و يا افرادى كه در جريان حريق واقع شداند بايد لباسهاى داراى الياف مصنوعى و پالاستيكى راز از خود دور كنيد. - در فرو نشاندن آتشسوزى سوختهاى نفتى از آب استفاده نكنيد. ــ ظرف مشتعل را حركت ندهيد. شعله را با شن، نمك، يتوى نمناك يا يوششهاى دينّر خفه كنيد. نكات ايمنى بعد از وقوع آتشسوزى و نجات مصدوم از اتاق ير دود. ـ ابتدا مطمئن شويد براى نجات مصدوم جان خود را به خطر نمىاندازيد. ـ طناب نجات را به كمر خود ببنديد و آن را به دست يكى از حاضران بدهيد. - روشى از نشانههاى قراردادى بين خود و كسى كه طناب را در دست دارد برقرار كنيد تا زمانى كه علامت داديد شما راب يرون بكشد. بهترين روش اين است كه طناب را به صورت دائم در حالت كشيده نتَه داريد و در هنكام خطر آن را شل كنيد تا فرد متوجه خطر شود و شما را بيرون بكشد. توجه: بستن دستمال تر به دور دهان و بينى باعث محافظت شما در برابر كاز يا دودهاى سمى خواهد شد. ـ مصدوم را بكيريد و با توجه به رعايت تمام جنبههاى ايمنى به سرعت به سمت در خروجى بكشيد. لباس سوخته مصدوم را با استفاده از يتو، كَليمه و يا كت خاموش كنيد. ـ اكر مصدوم هشيار باشد كاملأ إزاو مراقبت كنيد زيرا ممكن است، بر اثر نيم سوز شدن اشياى داخل اتاق، كُاز منواكسيد كربن در هواى اتاق ثراكنده شده باشُد و اين امر بر هوشيارى مصدوم به تدريج تأثير مى كذارد. ـ اكر تنفس هصدوم قطع شود بلافاصله تنفس هصنوعى را شروع كنيد وسيس هصدوم را به بيمارستان برسانيد.

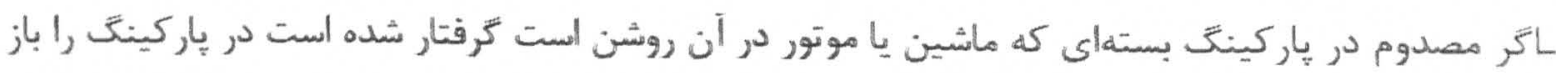


كنيد تا دود از يار كينَ خارج و هواز تازه به اندازه كافى وارد شود. نبايد وارد جنين محلهايى شويد مكَر آنكه مطمئن شويد خطرى جان شما را تهديد نخواهد كرد.

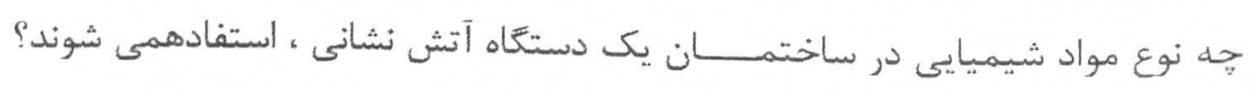

$$
\begin{aligned}
& \text { اين مسرواد جِّونه به خاموش شدن آتش كمك ميكند؟؟ }
\end{aligned}
$$

آتش خاموش كن ها بسته به كاربردى كه دارند ، شامل مواد شيميايى مختلفى هستند .خاموش كنتده هاى دستى كه اغلب درفروشتاه هاى ابزارالات عرضه مى شوند وبراى استفاده در آشَزخانه ها و كَارازَها مورد استفاده قرار مى كَيرند ، با نيتروزن يا كربن دى اكسيد تحت فشار مشخص، تنظيم شده و به منظور ايجاد جريسانى از عامل اطفاء حر يق از گسترش آتش سوزى جلوكَيرى مى كنند. در اينجا ماده موثر ممكن است يودرى مانند يتاسيمم هيدروخن كربنات، آب مايع ، يك عامل بيشران مانند فلوئوروكربن يا .... باشد. مؤثرترين و معروفترين فلوئوروكربن به كار رفته تاكنون برومو كلرو دى فلوئوروكربن بوده است كه با عنوان هالون III ا شناخته مى شود.

بر اساس يك توافقنامه ع بين المللى ،از سال 1994 توليد همه ى انواع هـــالونها متوقف شده است ـ زيرا اتمهلى برم و كلر موجود در اين مواد شيميـيى مى تواند با مهاجرت به لايه ى استراتوسفر هواكــــــــا

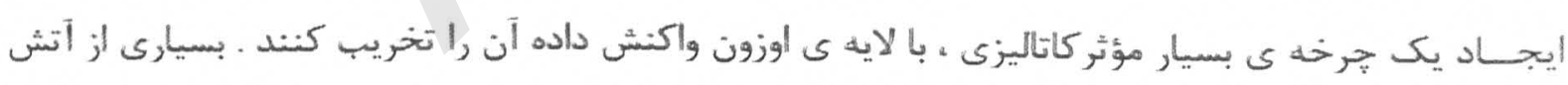
خاموش كن ها نيز براى محافظت از ساختمانها و ساير اماكن بزرگ تر مورد استفاده قرا ر مى گيرند . آب ياشهاى سقفى و ديوارى رايجترين نوع سيستم ثابت هستند زيرا ارزان و قابل اطمينان تر بوده و براى مردم عوارض جانبى به همراه ندارند ـ اما خسارت هاى ناشى از خود آب را همم نبايد ناديده كرفت ، مثلاً در يك اتاق كاميِيوتر ؛ يا خــــاموش كردن مخزن سوخت ؛ يا در جايى كه فضاى قابل توجهى ندارد و نتخهدارى مقادير زياد آب امكان هذير نيست ( مثلاً در هواييما)، نبايد از آب براى اطفاء حريق استفاده كرد.دراين حالات ، درتركيب 
آتش خاموش كن ها از مواد متفاوتى استفاده مى شود . برخى از آتش خاموش كنها با كمك يكى كاز به مقابله با آش مى روند ولى اين كاز در غلظتهاى بالا سمى است ، بنابراين در محلى كه افراد حضور دارند نمى توان از اين كَاز استفاده كرد .

\section{جلو كَبرى آنش سوزى ها:}

> هر شخصى بايد از خطر ات بعيار شُديد آتش عوزى كه منوجه خودش وخانو اده اش،خاته و محل كارش ميباشد آكَاه كَردد.

> موسسأت غير دوالتى ورمانه ها نقش حياتى در الين عر صه دارند.

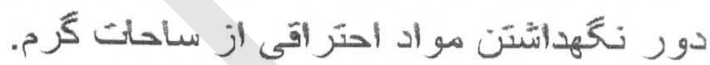
> خاموش سازى آن به اسرع وقت.

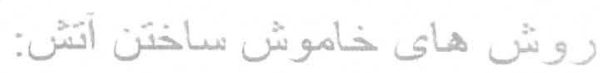

روش هاى اطفاء يا خاموش كردن آتش به اين صورت است 1 - كاهش درجه حرارت بوسيله سرد كردن كه اين كار با استفاده از آب صورت مى كيرد. r- كاهش درصد هوا يا اكسيجن و خفه كردن كردن آتش كه اين مرحله از اطفاء حريق نيز با كف و كاربن داى اكسايدصورت مى بذيرد.

ب- دور ساختن مواد سوختنى از محل آتش سوزى †- بطع عكس العمل كيميايى موتر هاى سازمان آتش نشانى همم هميشه محتوى ماده اطفايى آب و يا كف و يا هردو مورد ذكر شده است كه در (6) مخزن ماشين هاى آتش نشانى قرار داده ميشود. شكل (7-2)موتر اطفايه 


\section{فصل سوم}

: تحف 3.1

ساحسه مورد تحقيق ناحيه سيزدهم شهر كابل ميباشد.

3.2

هــدف از ايـن تحقيـق بررسـى تـاب آورى سـاختمان هـاى تجـارتى دردبرابــر آتش سـوزى در ولســو ناحيـه

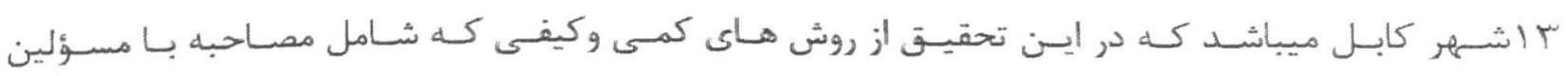

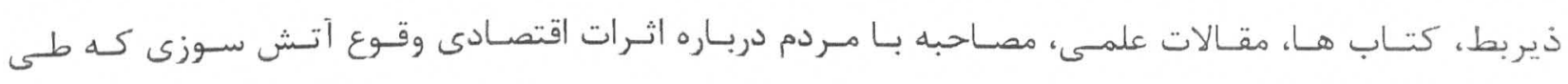

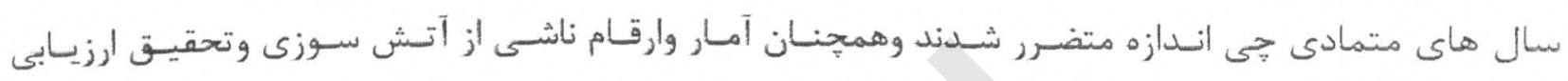
نمودن استفاده نموده ام.

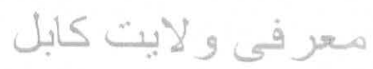

ولايبت كابل در زون مركزى كشورموقعيت دارد ، مركز آن شهر كابل است كه يايتخت افغانستان نيز ميباشد. اين ولايت در شمال غرب با يروان، در شمال شرق با كايِيسا، در شرق با لغمان، در جنوب شرق با ننكر هار، در جنوب با لوكر و در جنوب غرب باولايت ميدان وردگ سرحد مشترى دارد.

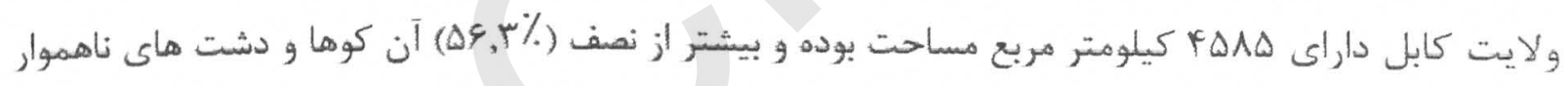
تشكيل ميدهد در حاليكه يك بر سه حصه آن (IV,V\%) رازمين هموار تشكيل ميدهد.

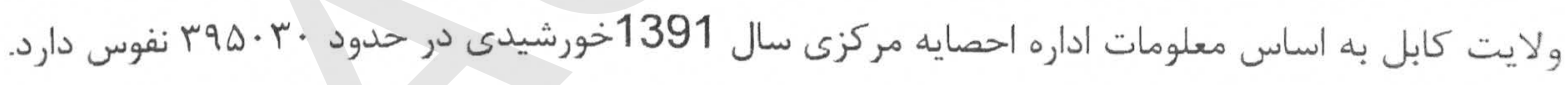

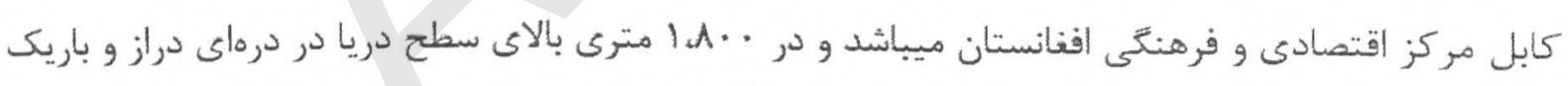
بين كوههاى هندوكش را شكافته و در طول درياى كايل امتداد يافته است. اين شهر همراه با ولايات كندهار ، هرات ومزار توسط بزرخراههاى حلقوى كه در سرتاسر كشور امتداد يافته وصل شده است. كابل همجنين مسير اهلى شاهر اه جلال آباد كه به سوى يشاور پإكستان مى رود ميباشد. كابل داراى اماكن تاريخى ، مساجد ، زيارتخاه ها ، باغهاى تاريخى و دروازه هاى مشهور، شاعراى نامى و نويسئده هاى بلند קايه ميبباشد. اين ولايت كه اقوام تاجكى ،يشتون و هزاره رادر خود جا داده أست مردم آن اغلبا به زبانهاى درى ويشتو تكلم نموده وسنى مذهب هستند. تعدادى از اهل تشييع، هندو و سيكها نيز در اين ولايت بويثه در مركز آن اقامت إن

دروازه هاي مشهور أين ولايت عبارت از دروازه سفيد ، دروازه لاهورى ، دروأزه كذر كاه ، دروازه سردارجانخان 
ميباشد . كوتل هاى ارغنده و خير خانه را هم دارا است

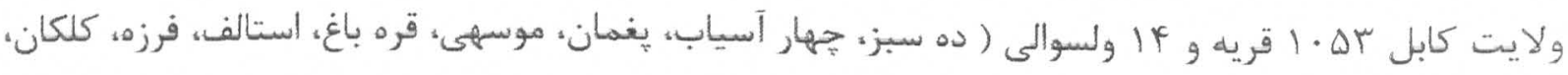

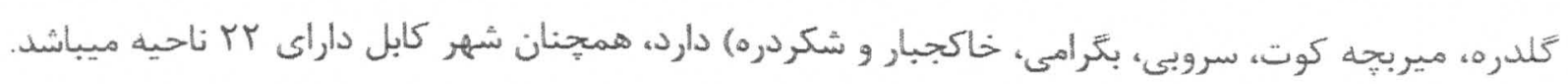

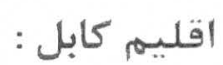
ساحه كابل با داشتن جهار فصل اقليم خشك دارد و سطح سالانه باران در ماهلى حمل و ثور . . ملى متر ميباشد.

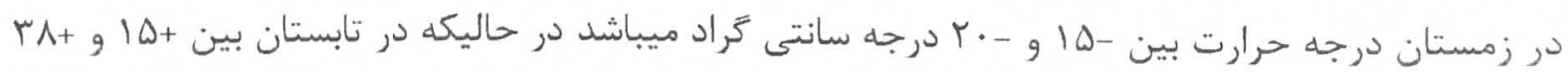
درجه سانتى كراد ميرسد. در جريان سال ماه جدى سردترين ماه به حساب هيرود كه درجه اوسط حرارت - T ادرجه ميباشد، همتِنان كر مترين آن ماه اسد ميباشد كه درجه اوسط حرارت به +ها درجه ميرسد. كابل يك دريا دارد كه به نام درياى كابل ياد ميشود، درياى كابل از كوهاى بغمان سر جشمه ميخيرد كابل دارنده سنتَ هاى قيمتى ميباشد، ماند لاجورد و ياقوت نيز ميباشد. آب و هواى كابل تابع وضع عمومى كشور افغانستان است و حون اين كشور تقريباً در وسط آسيا واقع است يس عرض و طول جنر افيائى و ارتفاع و امتداد كوهها و دورى از دريا همه از عواملى بشمار مىروند كه در آب و هواى افغانستان تأثير دارد.

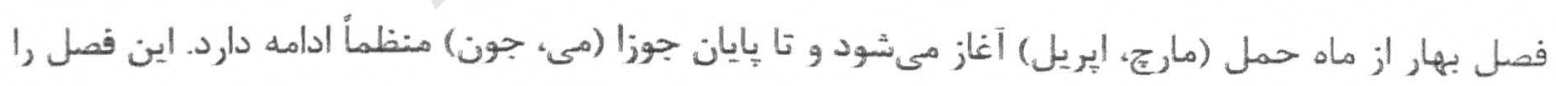

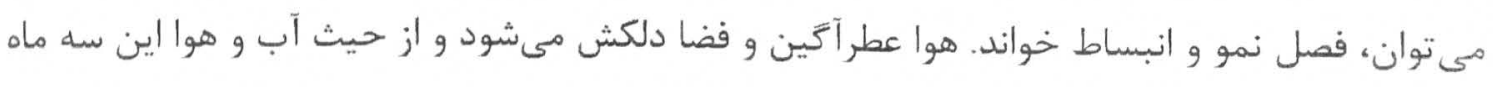
برازندهترين و نشاطانتَيزترين فصل هاى كابل مى باشند.

از ماه سرطان (جون، جولاى) تا آخر سنبله (اتَّت، سيتمبر) و موقع تابستان تَرمترين ايام كابل بهشمار مىرود،

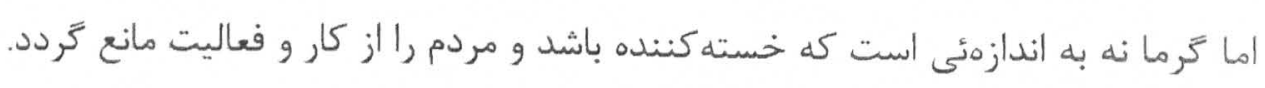
در ماه ميزان (سيتمبر و اكتبر) خزان آغاز مى تردد و تا هايان ماه قوس (نومبر، دسمبر ) ادامه دارد.

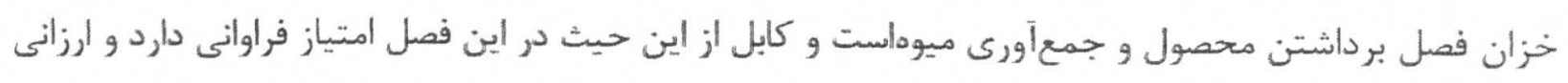
در همين موقع مىباشد. 
سه ماه اخير سال، جدى (دسمبر، جنورى)، دلو (جنورى) فبرورى) و حوت (فبرورى، مارج) فصل زمستان كابل

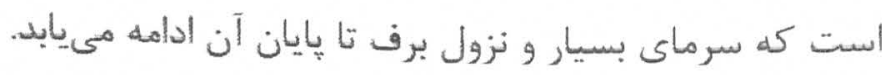

زراعت، مالدارى، تجارت، خدمات اجتماعى،صنايع و غيره منابع عايداتى أين ولايت ميباشد. ه, 1 1 آن در

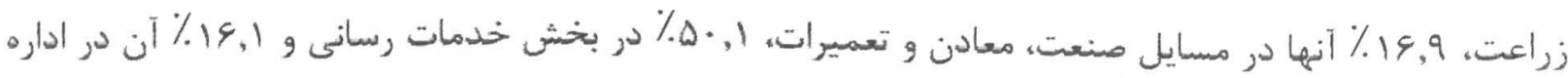
عامه يا حكومت مصروف ميباشد. محصولات عمده زراعتى اين ولايت را كندم، جو و ماش تشكيل ميدهد. در بخش باغات بهترين محصولات انتّور

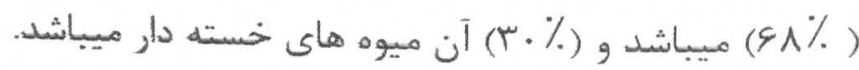

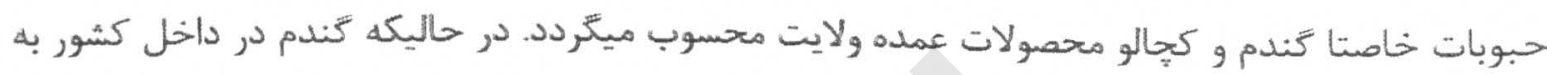

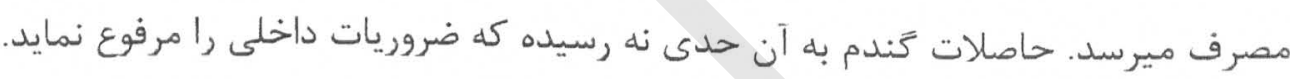

زلزله هاى كوجى، آشسوزى، سرازيرشدن سيلاب هاى و لغزش زمين از خطرات عمده اضطرارى اين ولايت زلزله هاى كوجى، ات اضشر ارى :

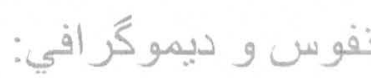

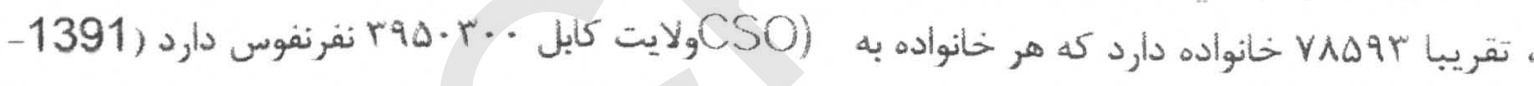

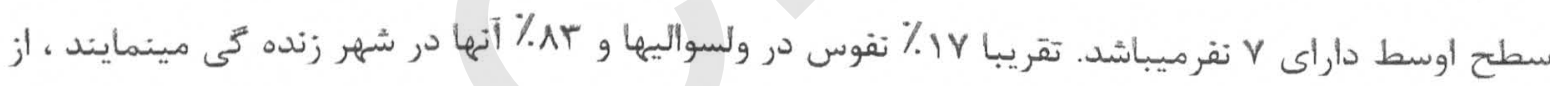

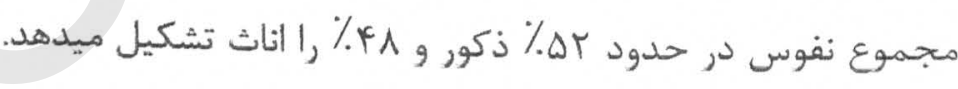

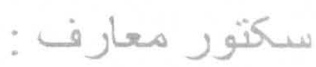

سكتورمعارف در كابل نسبت به سايرولايات ديكّر، بيشتاز بوده ؛ سيستم تعليمه و تربية دراين ولايت با آنكه

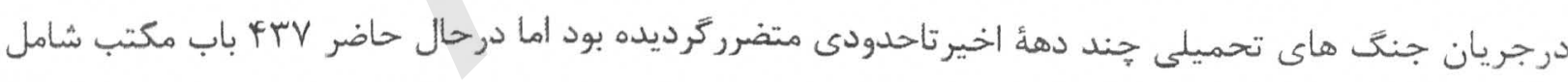

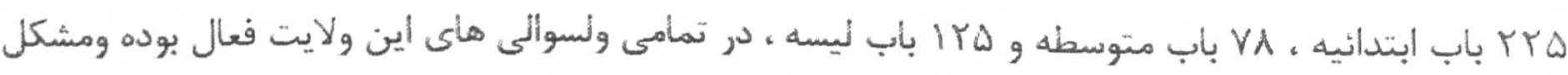
جدى دراين راستا وجود ندارد.

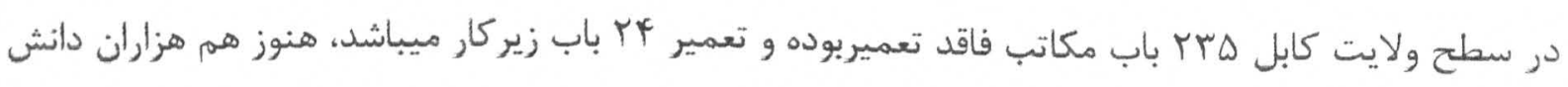

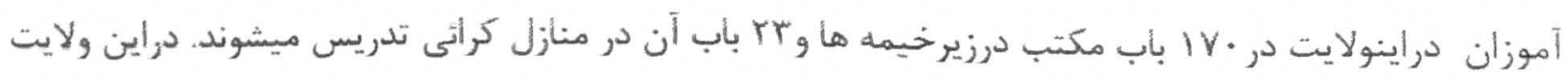

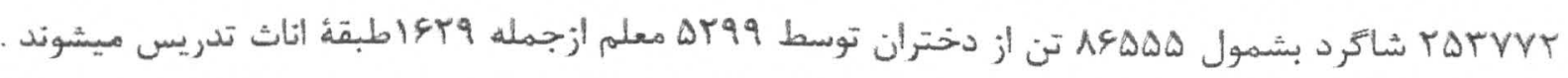
به اساس معلومات وزارت تحصيلات عالى ومسلكى درحال حاضر (rar I) درسطح كشور آيوهنتون 
د ولتى و • 1 يوهنتون خصوصى وموسسات تحصيلات عالى فعاليت دارد .

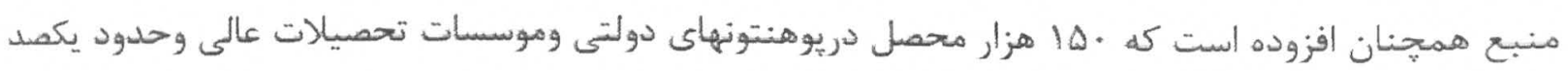

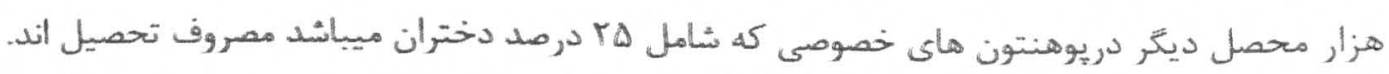
• 9 درصد مردم درولايت كابل از نوربرق مستفيد اند ، •ع فيصد سرك هاى در ولايت كابل قيريزى و متباقى خامه ميباشد .

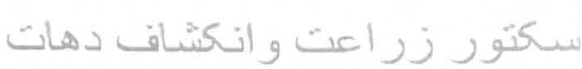

كابل يك ولايت زراعتى بوده و اقتصاد . و درصد مردم آن متكى به به زراعت و مالدارى است .

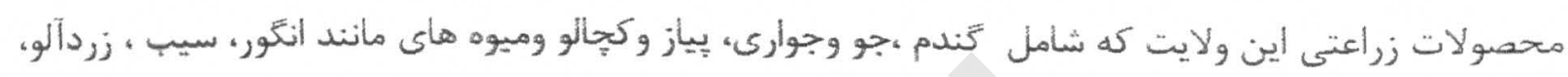

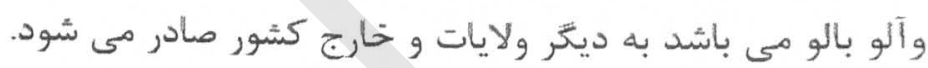

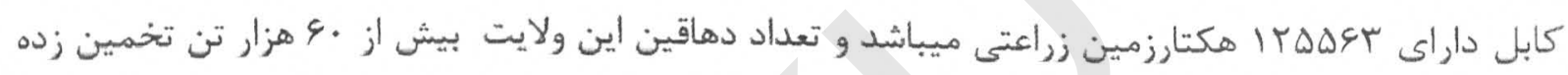
شده مى شود.

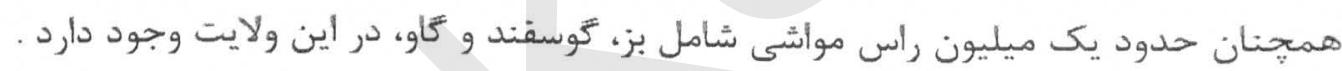

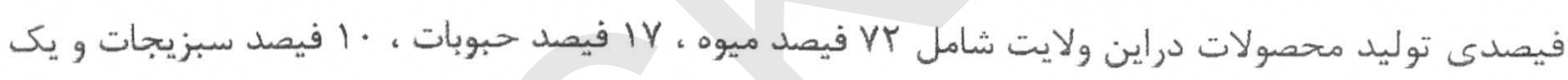
فيصد كرافس ميباشد .

فعاليت أل إ رسانه كروهى شامل ( آرانس خبرى ، تلويزيون ، راديو ، روزنامه ، هفته نامه ، دوهفته نامه ،

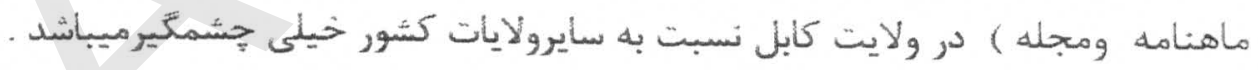

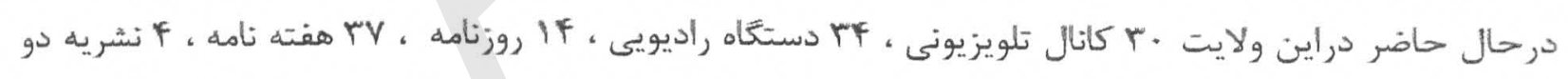

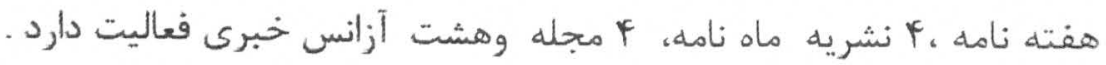

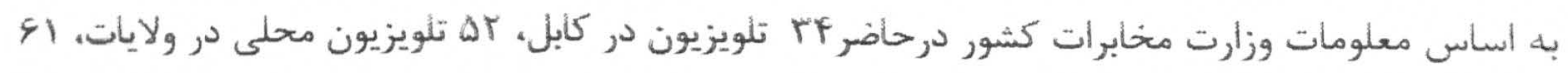

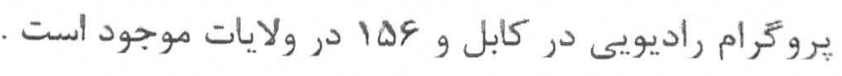


تاريخ سياسى ثُراز فراز و نشيب كابل همه سياستمداران جهان را متعجب نموده است حنانجه كابل هميشه ميدان جنَّ ها و تصادفات بوده و تاريخ با افتخار آن فراموش ناشدنى است شهر كابل در دامنه كوه آسمايى و شير دروازه، به هر دو طرف رود كابل آباد شده و از سطح بحر (دريا) قريب ششونيم هزار فوت ارتفاع دارد.

در زمان قديم در ترداترد شهر كابل ديوارهاى استوارى موجود بود كه إتباط شهر با نواحى آن با هفت دروازه صورت مى گرفت، امروز هم آثار ديوارهاى شهر بر كوه آسمايى و شيردروازه شاهد استحكام سابقه آن است. كابل اززمرة شهرى تاريخى و بسيار كهن است كه حوادث روزتار رابسيار ديده و خون بر جهارراه تجارتى شرق و شمال و جنوب وغرب واقع شده، اهميت تجارتى آن خيلى زياد است. كابل از حيث قدامت با قديمى ترين شهر هاى بلخ و باميان همسرى داشته و در كتاب ريتّودا، نام "كيسبهاه براى كابل استعمال شده است.

\section{مو قعيب جغز افبائى ناحبيه سبز دهم:}

از طرف شمال از قسمت هاى درياى كابل الى تّولائى مهتاب قلعهاز طرف جنوب به شهرك اميد سبز ،از طرف شرق به حوزه بنجهم و ششهم واز طرف غرب به سرك كه به طرف قندهار وهرات ميرود محدود شده است. معلومات : مساحت اراضى ناحيه سيزدهم 42kmميباشد.(شاروالى ناحيه سيزدهم شهر كابل) تمام نفوس ناحيه سيزدهم 640000فر بوده كه در 52000حولى و 80000 فاميل مسكن تزين شده است. در فى كيلو مترمربع ناحيه سيزدهم بيشتر از 10000 نفر زندكى ميكند.

مصرف روزانه هر فرد از منابع آبى بطور اوسط 120-150ليتر در روز است (UNEP) طبق سروى رياست آب رسانى شهر كابل هر فرد روزانه بطور اوسط در حدود 45 ليتر مصرف ميكند. هر هاه در هر ساعت بطور اوسط 62,5m³m آب توليد ميكند.(آمر يت آبرسانى افشار) فاصلد هر حلقه حاه آبى از هم ديكّر بايد 300-500متر باشد. 
در هر سال حدودا 30cm فاضلاب ها به آب هاى زير زمينى نزديك ميشود.وَّفته ميشود كه 30/آبهاى زير زمينى ناحيه سيزدهم شهر كابل به باكترياها آلوده است
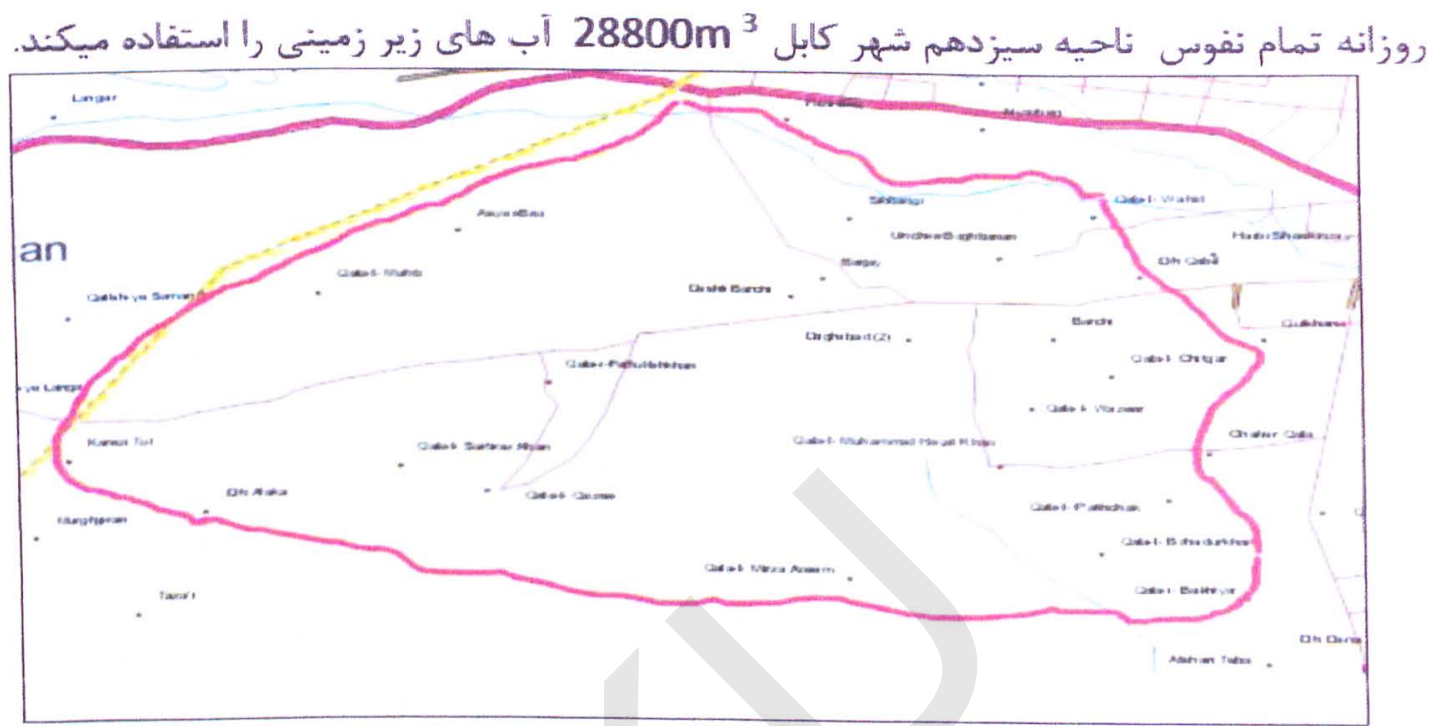

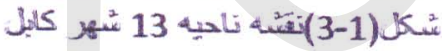

3.3

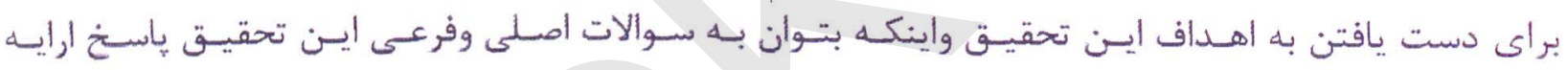

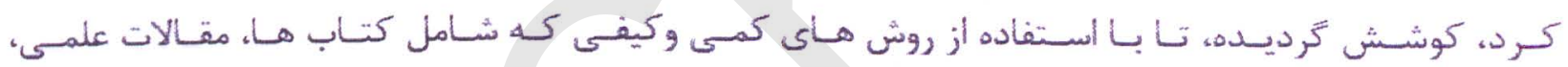

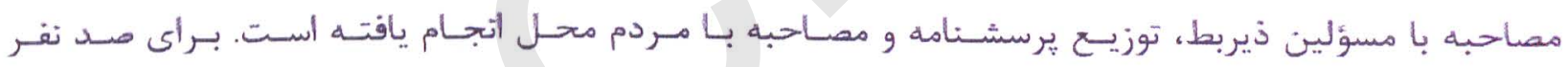

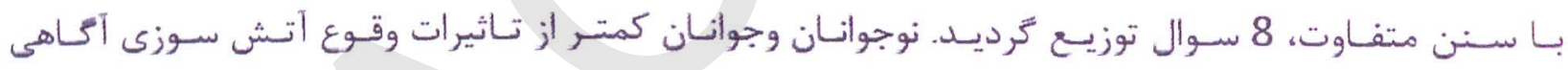

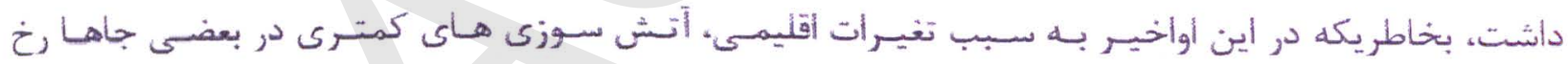
دأده است.كه آنمهم تاثيرات اش ناجيز بوده است.

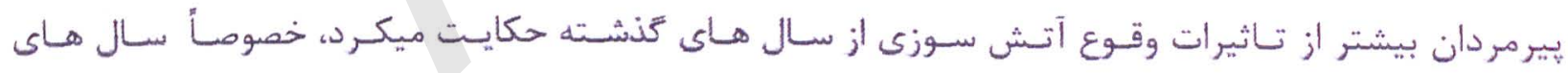
1330 الى 1370 كد آتش سـوزى هـاى بيشـترى رخ هيـداد كـ سـبب أز بسين رفـتن مسزارع وزمسين هـاى زراعتى شدند، كه بعضى وقت ها آتش سوزى بـه حـدى قـوى وشـدت آن بيشـتر بـوده كـه مـردم قريـه هــى خود را ترك ميكرد وبه تيه ها بالا ميشودند.

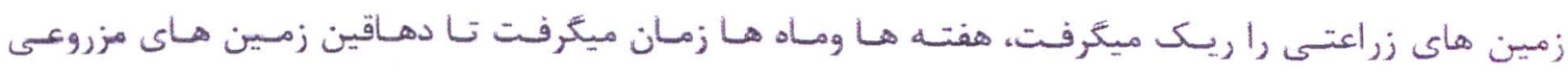

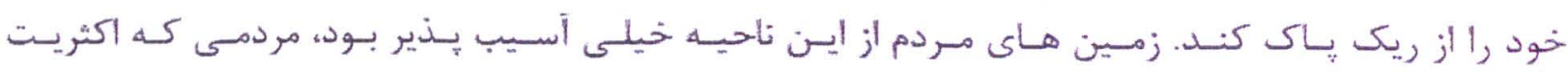
شان از طريق همين زراعـت ومالسفارى امـرار معيشـت ميكنـد. كـه آنهـمه تنها ميتوانـد از يسك فصـل سـال از زمين هاى زراعتى خود حاصل بيقرد. 


\section{فصل جهارم}

مصاحبات را كه با دكاكين و مسؤلين مراكز تجارتى در مورد آتشسوزى نموده ام قرار ذيل اند. 4.2.2 اين تحقيق با در داشت جنسيت، سن، شغل و سطح تحصيل در نظر كرفته شده است جهت وضاحت بيشتر كرافهاى ذيل طرح ترديده است .

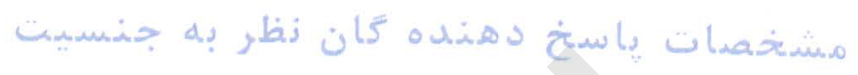

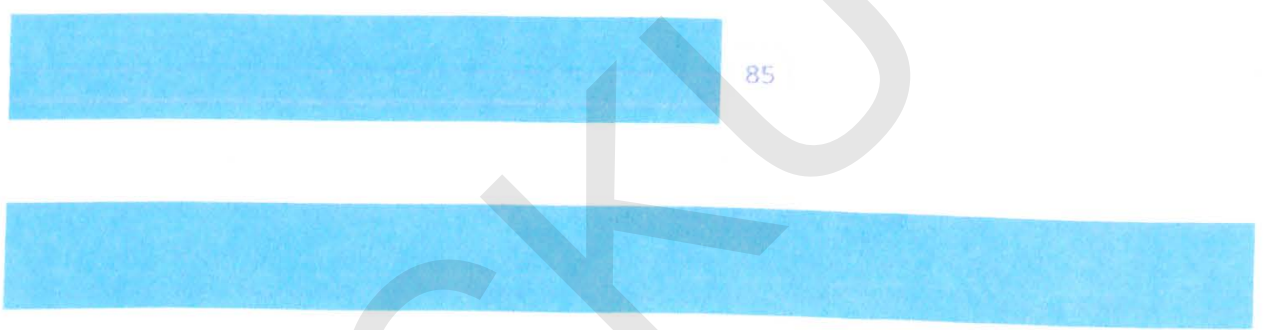

Fر اف (1-4)نشان دهنده مشخصات ياسخ دهنده ₹ان نظر جنسيت

كَر اف (4-2)نشان دهنده مشخصات ياسخ دهنده كان نظر سن و سطح تحصيل 


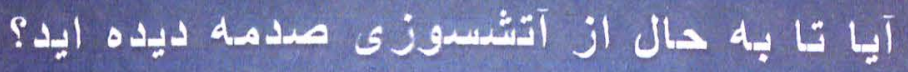

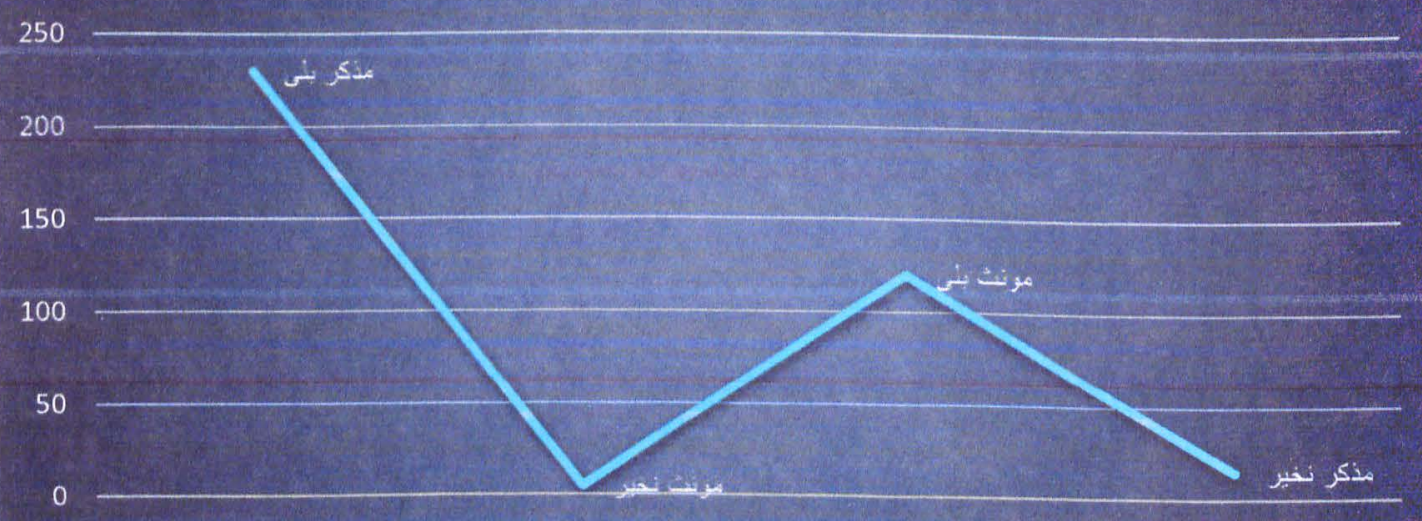

$$
\text { كراف (4-3)نشان دهنده آسيب ديدكان از آتشسوزى }
$$

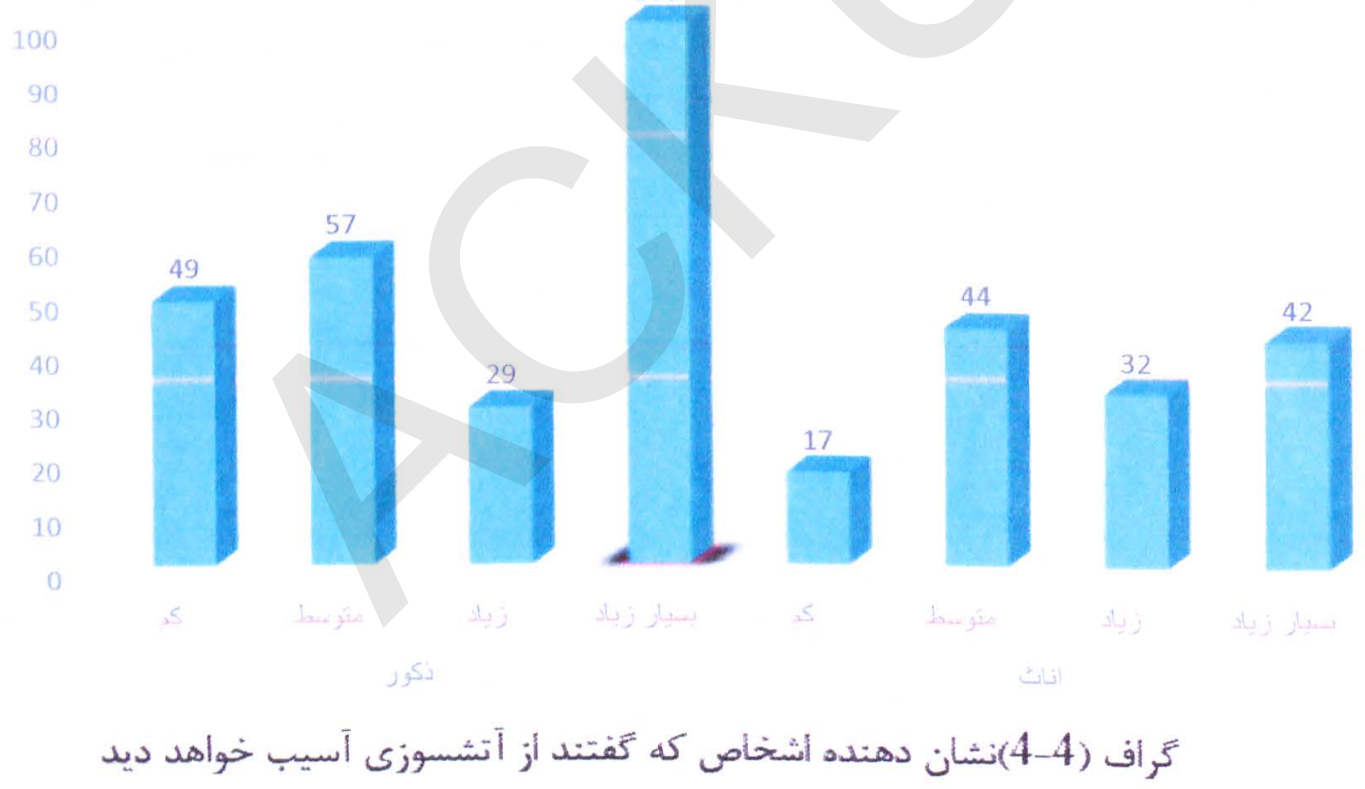




$$
\text { • ساختمانهاى تجارتى ناحيه سا شهر كابل جى اندازه در برابر آتش سوزى تاب آور استند؟ }
$$

بعضى ازساختمانهاى تجارتى در مقابل آتشسوزى بسيار آسيب خذير است زيرا هيحتّونه آمادكى وآكاهى در برابر آتشسوزى را ندارند. وميزان تاب آورى اين ساختمانها كم ميباشد.

$$
\text { واين ساختمانها اكثراً از اثر بى احتياطى دكاكين بوده كه آتشسوزى رخ ميدهد. }
$$

ساختمانهاى تجارتى ناحيه 13شهر كابل از لحاظ مدت فعاليت آنها جوان اند. قدامت زياد ندارد.نه همين جوان بودن آنها نشان ميدهد كه خيلى زياد متضرر نشده اند.

$$
\text { • آتش سوزى تا جى حد به ساختمان هاى تجارتى ميتواند صدمه برساند؟ }
$$

بنا به تحقيقات كه توسط من صورت كرّفته نشان ميدهد كه اين ناحيه ميتواند ضر رهاى زياد جانى و مالى را شاهد باشد.جون بى احتياط بودن و نبود امكانات يكى از دلايل عمده آتشسوزى است. كه مسؤلين و دكاكين هيج تونه آكَاهى و آمادكى براى مهار آتش راندارد. 


\section{فصل ينجم}

نتيجه كَيرى وييشنهادات:

: 5.1

آتشسوزى يا حريق يكى از قديمىترين بلايايى است كه ميتواند در زمانى كوتاه، دارايى و سلامتى افراد را به خطر اندازد.

دانشمندانى از آمريكا، آلمان، آفريقاى جنوبى در يروهش جديد خود دريافته اند كه انسان هاى اوليه از يك ميليون سال بيش از آتش استفاده مى كرده اند.

تسلط بر آتش يكى از نقاط عطف زندكى انسان بود. ساخت آتش به منظور ترما، بخت غذا و حقاظت صورت كرفتت. تخت غذا باعث شد تا هضم و جويدن غذاها ساده تر شده و مقدار انرزى قابل دريافت از مواد غذايى افزايش بيابد كه همين باعث مى شد تا وقتى كه انسان براى بيدا كردن و به دست آوردن غذا صرف كند كمتر بشود. تعيين زمان دقيق تسلط انسان بر آتش كار ساده اي نيست.

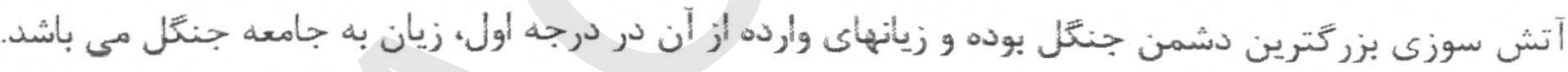

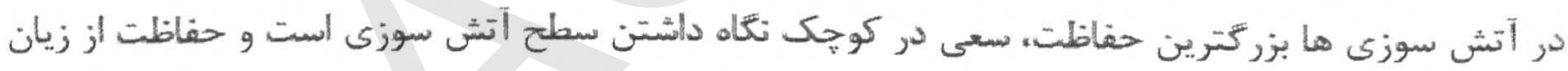

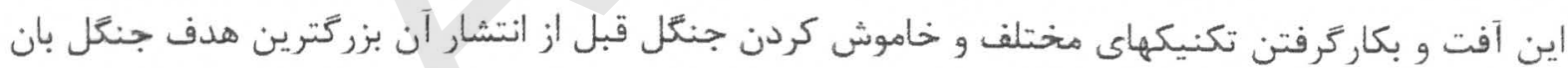
مى باشد.

آتش سوزى در جنكل بخاطر موقعيت مناطق جنتلى كه اغلب محيطى باز مى باشد، بصورت آزاد و بدون ايتكه با مانعى برخورد كند انتشار يبدا مى كند و به هر طرف بيشرفت كرده و در جهت هاى مختلف آتش سوزى ادامه ״ِيدا مى كند.

آتش سوزى در جنكّل بخاطر موقعيت مناطق جنتلى كه اغلب محيطى باز مى باشد، بصورت آزاد و بدون اينكه با مانعى برخورد كند انتشار ٍِيدا مى كند و به هر طرف بِيشرفت كرده و در جهت هاى مختلف آتش سوزى ادامه يى دا مى كند. 
تمام ساختمانهاى كه اعمار ميكردد بايد مطابق با نورم واستندرد باشد.بخصوص ساختمانهاى تجارتى.

$$
\text { آكاهى دهى عامه در برابر آتشسوزى. }
$$

$$
\text { احتياط و استفاده درست از وسايل كه ممكن باعث آتشسوزى گردد. }
$$$$
\text { نصب زنغ هوشدار در ساختمان هاى تجارتى. }
$$

استفاده از سيستم ضد حريق در ساختمان ها واستفاده از بالون هاى ضدحريقدر هنكام آتشسوزى. هر دوكان دار بايد يك بالون ضد حريق با خود داشته باشد. تا در هنكام حريق بتواند به همان ساختمان كمك نموده واز شديد شدن آتشسوزى جلوكيرى نمايد.

$$
\text { • • ايجاد سيستم هاى آتش نشانى در اين ناحيه. }
$$




$$
\begin{aligned}
& \text { 1. فقيرى عصمت نسرين.(1397) مديريت حوادث }
\end{aligned}
$$

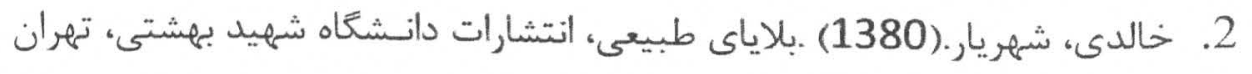

$$
\begin{aligned}
& \text { 3. صادقيان، محمد صادق . (1392) .مديريت سيلاب شهرى، انتشارات نوآور، تهران }
\end{aligned}
$$

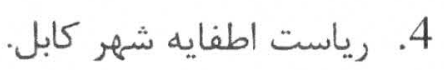

$$
\begin{aligned}
& \text { 5. رياست ناحيه سيزدهم شهر كابل. }
\end{aligned}
$$

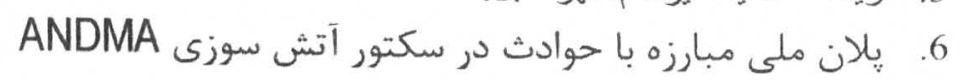

7. Abbortt, P.L (2004).Natural disaster. Mcgraw Hill. New York. P 50.

8. Stephenson, R. S., (1991): Disaster Assessment. Published: UNDP.

9. Samad, Muhammad (2002). Participation of the Rural Poor in Governament and NGO Programs. Dhaka.

10. http://mew.gov.af/fa/article/33114

11.http://www.afghanpaper.com/nbody.php?id=151120 

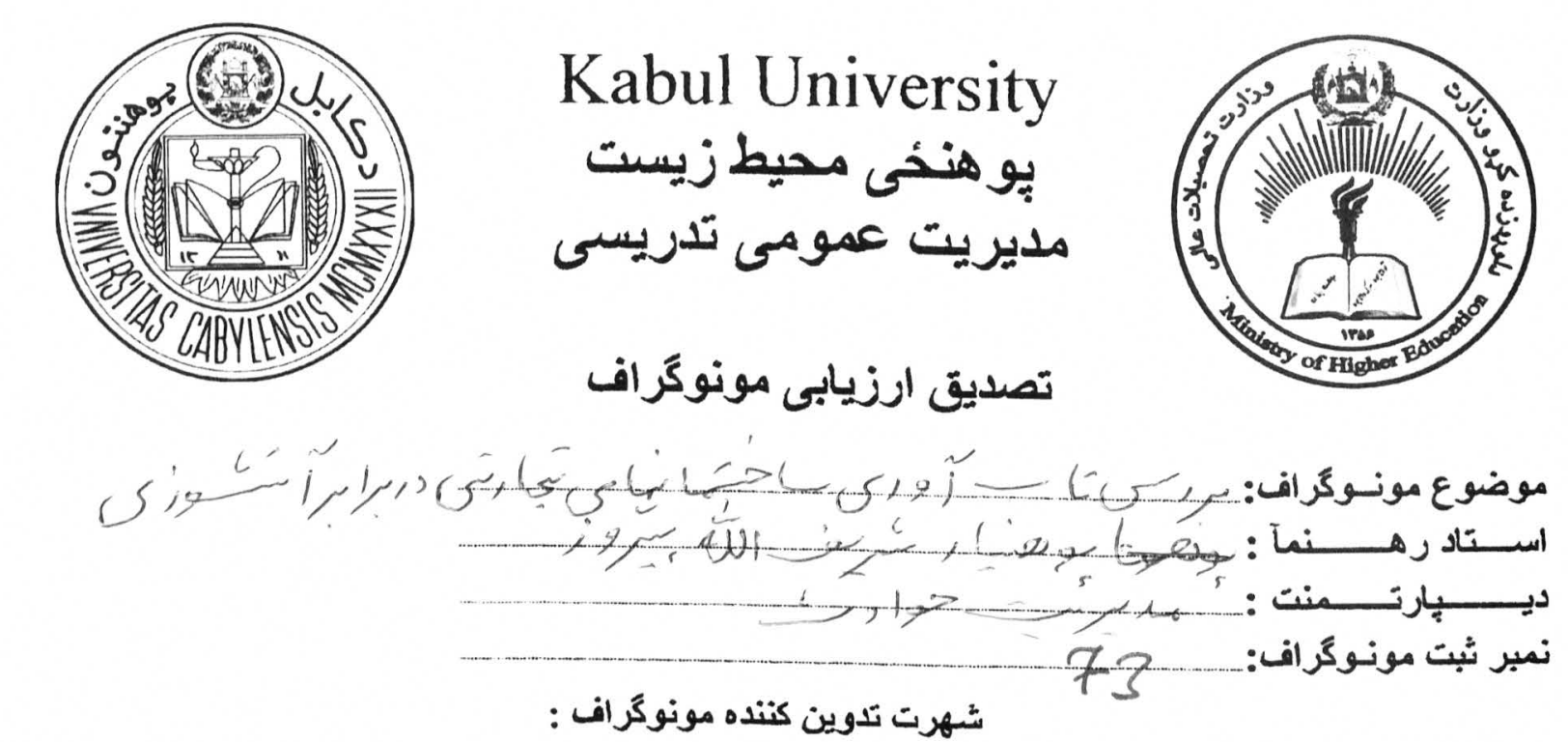

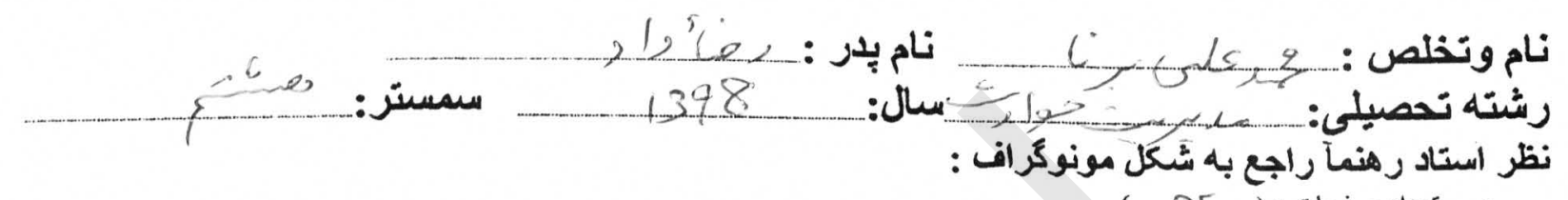

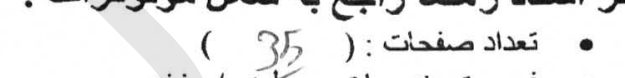

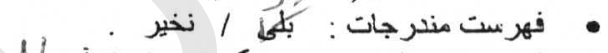

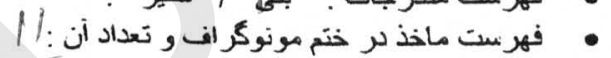

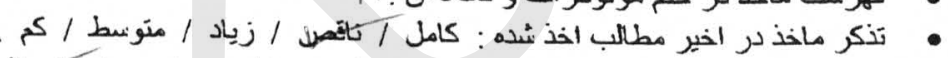

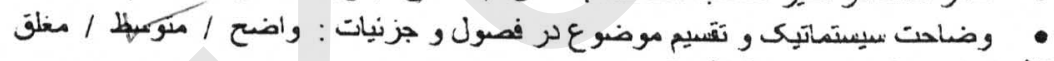

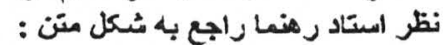

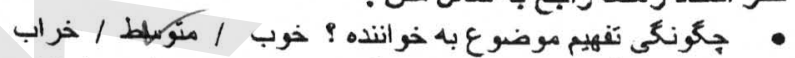

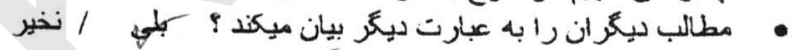

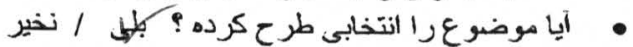

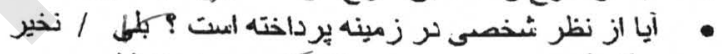

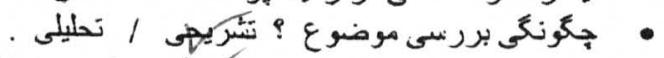

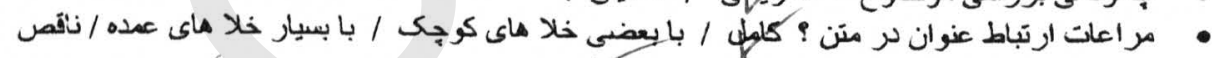

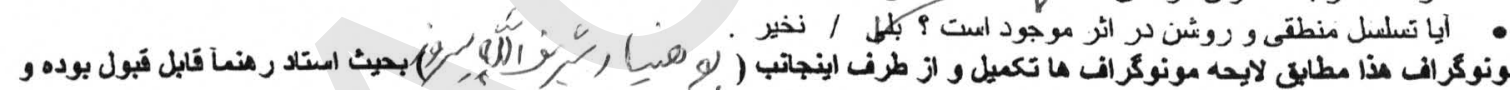

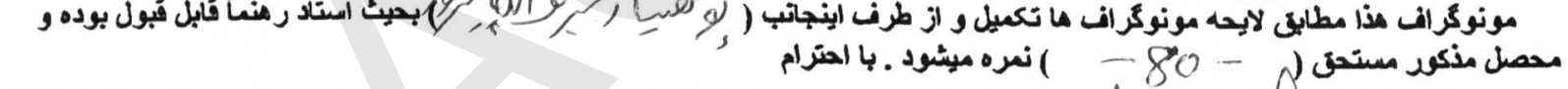
تاريغ / 1398
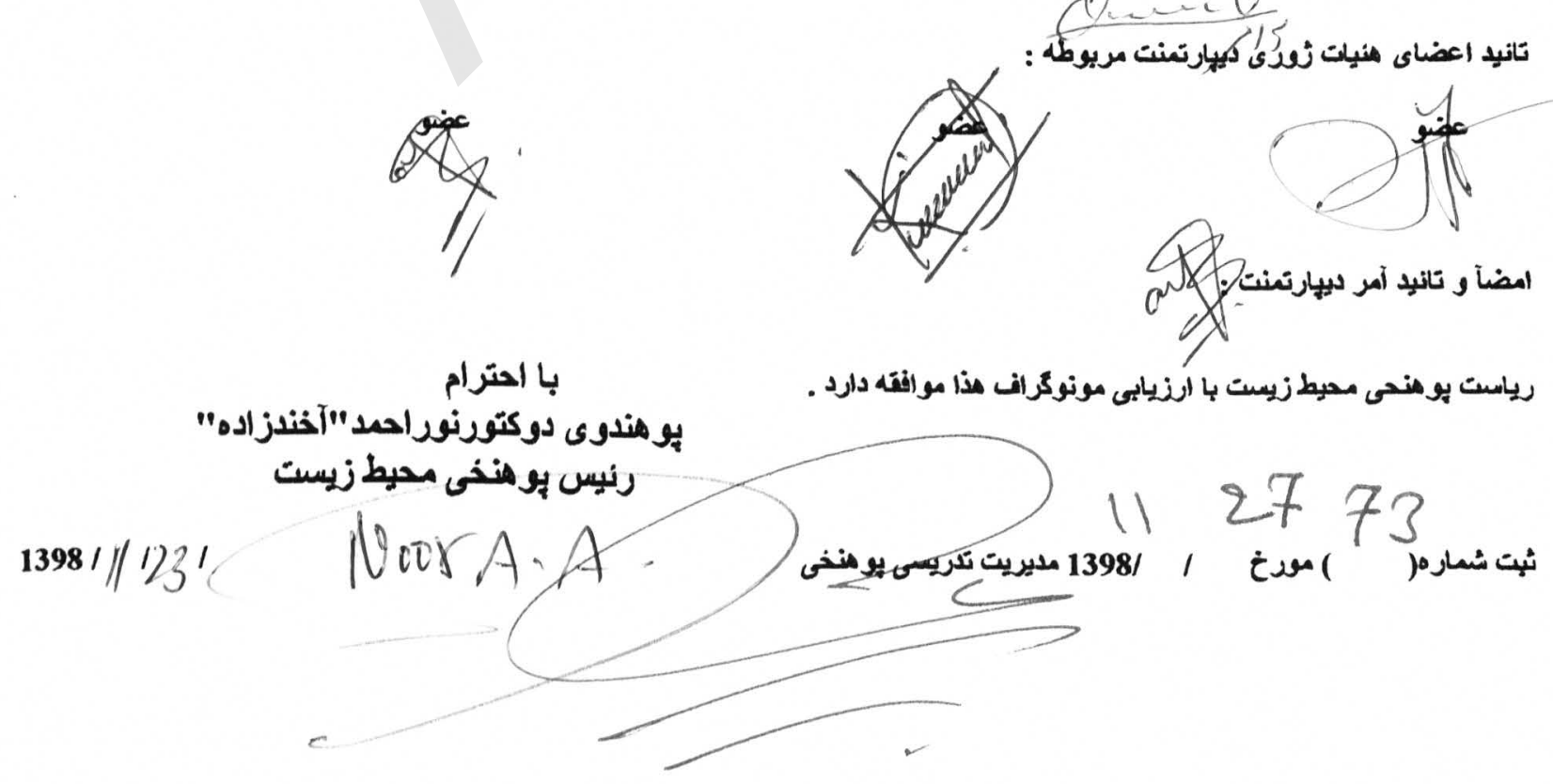


\section{Research Summary}

This study will examine the effects of fire on commercial centers and identify the factors that make the area more vulnerable to a fire incident. It also identifies the centers most at risk of a fire incident. I study the effects of fire.

Before going into the main topic of the public debate, including the problem design, the importance of the research, the purpose of the research, and the research questions, I will discuss the general outcome

In the first chapter of this research, topics related to the research background, research methodology, research questions, research objectives, research area, Kabul province introduction and introduction to the thirteenth district are discussed, and in the background section, what works on the topic or topics? The subsidiary has so far been dealt with in Afghanistan or outside countries

And in the Research Methodology section that deals with topics such as the research area, information and sources of information as well as the method of information analysis.

In the first chapter of this research, topics related to the research background, research methodology, research questions, research objectives, research area, Kabul province introduction and introduction to the thirteenth district are discussed, and in the background section, what works on the topic or topics? The subsidiary has so far been dealt with in Afghanistan or outside countries. And in the field of research that deals with issues such as the area of research, information and information resources, as well as the method of information analysis.

The second chapter of this research discusses the generalities and definitions of fires, characteristics of fires, types of fires, its causes, human and natural factors, and discusses the effects of fires. Has been. And in the last chapter of this research, suggestions and references are mentioned.

Keywords: -Anstruction, Fire Extinguishers, Business Centers, Fire Extinguishers, survey 


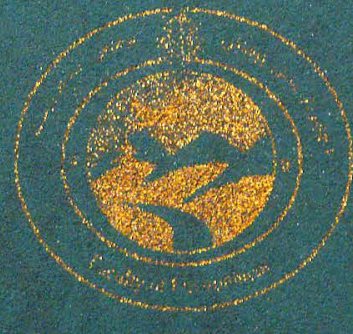

Kainu niveraits:

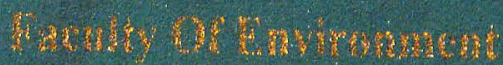

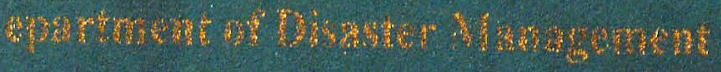

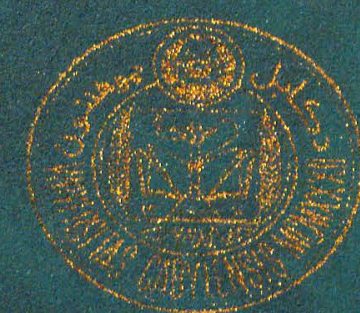

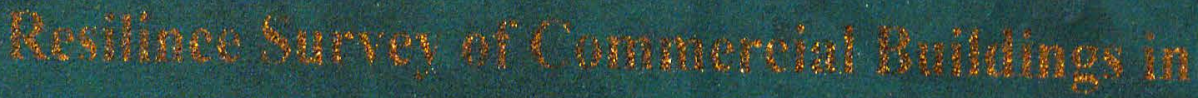

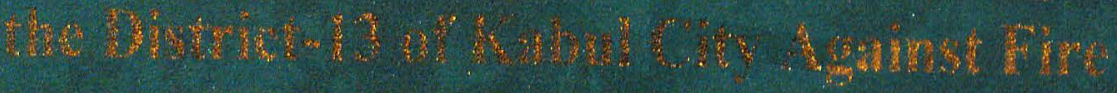

